\title{
Cymothoa frontalis, a cymothoid isopod parasitizing the belonid fish Strongylura strongylura from the Malabar Coast (Kerala, India): redescription, description, prevalence and life cycle
}

\author{
Aneesh Panakkool Thamban', Sudha Kappalli ${ }^{*}$, Helna Ameri Kottarathil', Anilkumar Gopinathan²
} and Trilles Jean Paul ${ }^{3}$

\begin{abstract}
Background: Cymothoa frontalis Milne Edward, 1840 is a very poorly described cymothoid, notwithstanding the previous redescription of the female. Pertinently, to date, the host of $C$. frontalis has not been identified with adequate precision. Most of the descriptions of cymothoids carried out hitherto were based primarily on females, but practically ignoring other life cycle stages. The present paper redescribes the female and describes other life cycle stages of the species $C$. frontalis to get better precision in their identification.

Results: The female phase of $C$. frontalis is redescribed according to type specimens extant in the NMNH, Paris, and also by the data obtained from live specimens collected during the present study. The general morphology and appendages of various life cycle stages of the species are described. Among 80 fish species from 35 families examined, C. frontalis was recovered only from Strongylura strongylura signifying its oligoxenous host specificity, the prevalence and intensity being $68.65 \%$ and 1.9, respectively. Each host fish in more than $85 \%$ of the population was infested with a pair of $C$. frontalis, in three combinations, predominantly with male-female pair (70.9\%). C. frontalis exhibited strict site specificity attaching to the buccal cavity of the host fish. The study has also identified three major phases (marsupial, free living and infective) in the life cycle of $\boldsymbol{C}$. frontalis. The zygotic-staged marsupiumites were developed through five sequential ontogenetic stages. The manca released from the marsupium become infective after a brief period of free swimming life. During the infective phase, $C$. frontalis completes remaining life cycle stages with successive moulting. Further, six successive stages of the ovigerous females have also been identified.

Conclusions: The present redescription of the female and the description of transitional, male, juvenile and larvae of $C$. frontalis facilitate precise identification of the species at any stage of the life cycle. Further, the strict host and site specificities of the parasite, as borne out from the present study, and its high degree of prevalence in the host make $C$. frontalis as an ideal model organism to study the strategies to be adopted for the management of parasites infesting edible fishes.
\end{abstract}

Keywords: Cymothoa frontalis; Cymothoidae; Redescription; Description; Prevalence; Life cycle; Strongylura strongylura; India

\footnotetext{
* Correspondence: ksudha50@rediffmail.com

${ }^{1}$ Post Graduate Department of Zoology and Research Centre, Sree Narayana College, Kannur 670 007, India

Full list of author information is available at the end of the article
} 


\section{Background}

Cymothoids are ectoparasitic isopods parasitizing teleost fishes inhabiting diverse ecosystems (Trilles 1968, 1994; Brusca 1981; Seng and Seng 1990; Horton and Okamura 2001; Trilles et al. 2011; Hadfield et al. 2013; Aneesh et al. 2014) and have been shown to cause deleterious effects on their hosts (Trilles and Hipea-Jacquotte 2012). For instance, the anemone fish Amphiprion akallopisos, Stolephorus commersonii and Hemiramphus far were severely damaged due to the parasitic infestation by Renocila heterozota, Nerocila phaeopleura and Mothocya plagulophora, respectively (Bowman and Mariscal 1968; Rajkumar et al. 2006; Gopalakrishnan et al. 2010). Five species of Nerocila ( $N$. acuminata, N. phaiopleura, N. loveni, $N$. depressa and $N$. longispina) were reported to have induced severe tissue damage in seven fish species such as Gymnothorax eurostus, Thryssa malabarica, Thryssa mystax, Thryssa setirostris, Coilia dussumieri, Opisthopterus tardoore, Escualosa thoracata and Ambassis ambassis (Bowman 1960; Aneesh et al. 2013a). Further, seasonal fluctuations in the population of four Nerocila species were reported from the Malabar Coast of India (Aneesh et al. 2013a). Recent studies conducted in our laboratory have shown profuse infestation of the Indian mackerel Rastrelliger kanagurta and the slender needle fish Strongylura leiura by Norileca indica and Mothocya renardi, respectively (Aneesh et al. 2011, 2013b). Most of the taxonomic descriptions of the cymothoids are based primarily on ovigerous females; the various life cycle stages (excepting perhaps the premanca/manca of few Cymothoa sp.) have not received much attention thus far (Richardson 1905; Sartor and Pires 1988; Thatcher et al. 2003, 2007; Trilles and Bariche 2006; Hadfield et al. 2011). Keeping these in view, the present paper addresses the question of precise identification of the cymothoid $C$. frontalis infesting the belonid fish inhabiting the Malabar Coast.

The genus Cymothoa Fabricius, 1793 comprises about 50 species which usually infest the tongue of the host fish (Trilles 1994; Schotte et al. 2008); some of them are reported to induce atrophy of the host's tongue (Brusca 1981; Romestand and Trilles 1977; Hadfield et al. 2011, 2013).

Cymothoa frontalis (Milne Edwards, 1840) is a poorly described one, and though the female stage of this species was redescribed by Schioedte and Meinert (1884), their Latin redescription seems inadequate in terms of modern standards. In spite of being a protandric hermaphrodite, only the female stage was subjected to detailed examination thus far; further, its host was not accurately identified even though a single host 'Cyclopterus' was doubtfully reported by White (1847). The present study depicts a redescription of the female stage of $C$. frontalis. It also describes all the other life cycle stages (transitional stage, male, juvenile manca and pre- manca) of this cymothoid using the live samples collected afresh from the Indian spot tail needle fish Strongylura strongylura (Beloniformes, Belonidae). The study also brings out the results of our thorough observation on the host specificity, site specificity, prevalence, intensity and life cycle of the species.

\section{Methods}

Live marine fishes were collected freshly from the Ayyikkara fish-landing centre (Lat. $11^{\circ} 51^{\prime} \mathrm{N}$, Long. $75^{\circ} 22^{\prime} \mathrm{E}$; Malabar Coast, India). The various body parts of the fish were examined (immediately after collection) for the presence of cymothoids using a hand lens. The recovered parasites with their host were brought to the laboratory and subjected to detailed examination with the aid of a stereomicroscope (Leica-S6D, Leica Microsystems Ltd., Milton Keynes, UK). The cymothoids thus obtained were preserved in 75\% ethanol (after Ramakrishna 1980) and subjected to further taxonomical identification. The survey was conducted twice a week round the year from November 2009 to November 2012. The prevalence $(P)$ and intensity $(I)$ of the recovered $C$. frontalis were calculated as per the methods described in Margolis et al. (1982) and Bush et al. (1997). The total length of the fish host as well as the parasite (C. frontalis) was measured to the nearest $1 \mathrm{~mm}$. Mouthparts and appendages of the parasite were carefully dissected out using a dissecting needle and a fine pair forceps and observed under the microscope (Leica DM-750). The drawings of the observed mouthparts and appendages were performed using a camera lucida attached to the microscope. The moult stages and the moult-related changes of the parasite were determined through the macroscopical and microscopical observations on the characteristic changes occurring in the carapace and the appendages (after Sudha et al. 2012). The reproductive activity was assessed through microscopic observations of the ovary (after dissecting out) and marsupiumites (after Sudha et al. 2012; Aneesh 2014). Classification of the marsupial stages was carried out taking cues from Bakenhaster et al. (2006). Fish taxonomy and host nomenclature were performed according to FishBase (Froese and Pauly 2012). Voucher specimens were deposited in the collections of the Parasitic Crustacean Museum, Crustacean Biology Research Laboratory, Sree Narayana College, Kannur, Kerala, India.

\section{Results}

\section{Systematics}

Suborder: Cymothoida Wagele, 1989

Superfamily: Cymothooidea Leach, 1814

Family: Cymothoidae Leach, 1814

Genus: Cymothoa Fabricius, 1793

Restricted synonymy: Fabricius 1793: 503; Milne Edwards 1840: 264-269; Schioedte and Meinert 1884: 223-225; 
Kussakin 1979: 289; Brusca 1981: 185; Trilles 1994: 137; Hadfield et al. 2013: 153.

Type species: Oniscus oestrum Fabricius, 1793, by subsequent designation (Kussakin 1979).

Cymothoa frontalis Milne Edward, 1840

Cymothoa frontale (Cymothoé frontal) Milne Edwards 1840: 271.

Cymothoa frontalis - White 1847: 110-?; Dana 1853: 750-751, pl. 49, Figure twelve (a-b); Schioedte and Meinert 1884: 226-228, tab. VI (Cym. XXIV), Figures one and two; Gerstaecker 1901: 261; Nierstrasz 1931: 136; Trilles 1975: 980-981, pl. 1; Avdeev 1978: 282; Avdeev 1979: 53; Avdeev 1990: 32-42; Trilles 1994: 143.

\section{Material examined:}

Type material: Ovigerous female (LT. $24 \mathrm{~mm}$ ) and nonovigerous female (LT. $18 \mathrm{~mm}$ ), Mer des Indes, Dussumier, Cymothoa frontalis M. Edw., type (MNHN N 202$)$.

Non-type material: From S. strongylura, Ayyikkara fish landing centre (Lat. $11^{\circ} 51^{\prime} \mathrm{N}$, Long. $75^{\circ} 22^{\prime} \mathrm{E}$ ), Malabar Coast, India; collected by Aneesh, P. T., Helna A. K. and Sudha, K. and deposited in the PCM. Ovigerous female (LT $26 \mathrm{~mm}$ ) with manca in the brood pouch (PCM N CF-09), 12 July 2011; non-ovigerous female without brood pouch (LT $28 \mathrm{~mm}$ ) (PCM N ${ }^{\circ}$ CF-06), 16 August 2010; ovigerous female with pre-manca in the brood pouch (LT $23 \mathrm{~mm}$ ) (PCM N ${ }^{\circ}$ CF-04), 19 May 2010; ovigerous female with eggs in the brood pouch (LT $23 \mathrm{~mm}$ ) (PCM N ${ }^{\circ}$ CF-01), 8 December 2009; ovigerous female with eggs in the brood pouch (LT $21 \mathrm{~mm})\left(\mathrm{PCM} \mathrm{N}^{\circ} \mathrm{CF}-03\right), 16$ January 2010; male (LT $13 \mathrm{~mm}$ ) (PCM N $\mathrm{N}^{\circ}$ CF-02), 8 December 2009; transitional stage (LT $20 \mathrm{~mm})\left(\mathrm{PCM} \mathrm{N}^{\circ}\right.$ CF-08), 25 April 2011; juvenile (LT $8 \mathrm{~mm}$ ) (PCM N ${ }^{\circ}$ CF07), 13 March 2011; 30 manca released by the specimen PCM N ${ }^{\circ}$ CF-09 (LT 3.2 to $3.4 \mathrm{~mm}$ ), (PCM N ${ }^{\circ}$ CF-10), 12 July 2011; 20 pre-manca collected from the brood pouch of the specimen PCM N ${ }^{\circ}$ CF-04 (LT 2.2 to $2.4 \mathrm{~mm}$ ) (PCM $\mathrm{N}^{\circ}$ CF-05), 19 May 2010.

\section{Redescription of the ovigerous female}

Body about 2.6 times as long as wide, widest at pereonites 5 to 6 (Figures 1D, 2, 3 and 4; Table 1). Cephalon partially immersed in poorly developed amphicephalic process of pereonite 1, as long as wide, anterior margin truncate. Eyes relatively smaller than male, not much developed but moderately distinct. Coxae not visible in dorsal view. Pereonite 1 longest, pereonites 2 to 4 subequal in length; pereonites 5 to 7 decreasing in length progressively, pereonite 7 shortest. The pereonites increase in width from 1 to 6 ; pereonite 6 widest and slightly wider than pereonite 7. All the pleonites visible, increasing progressively in width posteriorly from 1 to 5 ; pleonite 5 widest and longest. Pleotelson 1.6 times as wide as long, wider than pleonite 5 , posterior margin broadly rounded.
Antennule stouter than antenna, subequal in length to antenna, composed of 8 articles, extending to anterior margin of pereonite 1 ; articles 1 to 3 slightly wider than others. Antenna with 9 articles, decreasing gradually in width, distal margin of articles 6,7 and 8 with 3 to 6 setae. Article 9 with 3 to 6 terminal aesthetascs. Mandible palp 3 segmented, without setae in ovigerous female. Maxillule with 4 apical spines slightly recurved. Bi-lobed maxilla with 2 spines on median lobe and 1 spine on lateral lobe. Maxilliped with oostegial lobe with many plumose setae and a palp with 3 small apical and 2 lateral recurved spines on article 3 .

Pereopods gradually increase in size from 1 to 7, without spines; basis increasing in width progressively from pereopods 1 to 7 . Pleopods not distinctly visible in dorsal view; pleopod 2 without appendix masculina. Endopods of pleopods 4 and 5 moderately and strongly folded, respectively. Uropod rami short, not reaching the distal margin of pleotelson; rami subequal in length, curved and apically rounded.

Brood pouch with 4 pairs of overlapping oostegites arising from the bases of pereopods 2, 3, 4 and 6 . Number of eggs or larvae per brood pouch ranges from 320 to 520 according to the size of the female.

\section{Description of the male}

Relatively smaller than ovigerous female and transitional stage (Figures 1B, 5 and 6; Table 1). Body 2.67 times as long as wide. Cephalon not immersed in pereonite 1 . Eyes small but more prominent than in the female.

Pereonite 1 longest, pereonites 5 and 6 subequal in width and widest. Coxae not visible in dorsal view. All pleonites visible increasing progressively in width posteriorly; pleonite 5 widest and longest. Pleotelson 2 times as wide as long, slightly wider than pleonite 5 , posterior margin broadly rounded.

Eight articled antennule stouter and subequal in length to antenna. First 3 articles slightly wider than others. Antennae 9 articled, decreasing gradually in width, distal margin of articles 6,7 and 8 with 3 to 6 setae; article 9 with 3 terminal aesthetascs. Mandible palp 3 segmented, articles 2 and 3 with several setae on distolateral margin. Maxillule with 4 apical spines slightly recurved; maxilla bi-lobed, with 2 spines on median and lateral lobes. Maxilliped without oostegial lobe and a palp with 3 small apical and 2 lateral recurved spines on article 3.

Pereopods 1 to 7 gradually increasing in size, without spines; basis increasing in width progressively. Penes visible on sternite 7. Pleopods not distinctly visible in dorsal view. Pleopod 2 with appendix masculina. Endopodite of pleopods 4 moderately and 5 strongly folded. Uropod rami, nearly reaching the distal margin of pleotelson; rami subequal in length, curved and apically rounded. 


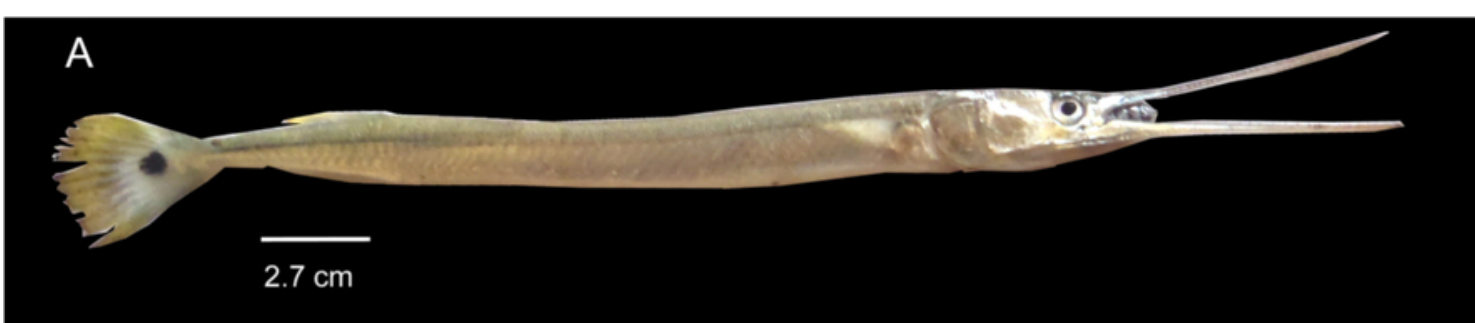

B

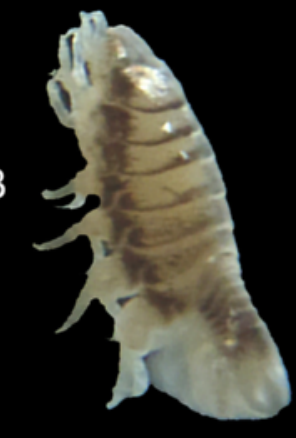

$3 \mathrm{~mm}$
C

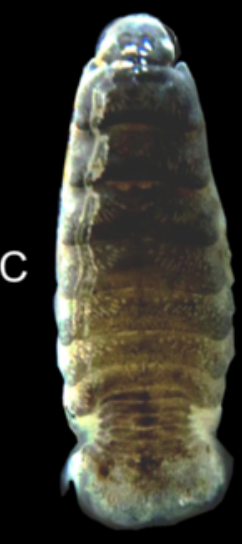

$3.85 \mathrm{~mm}$
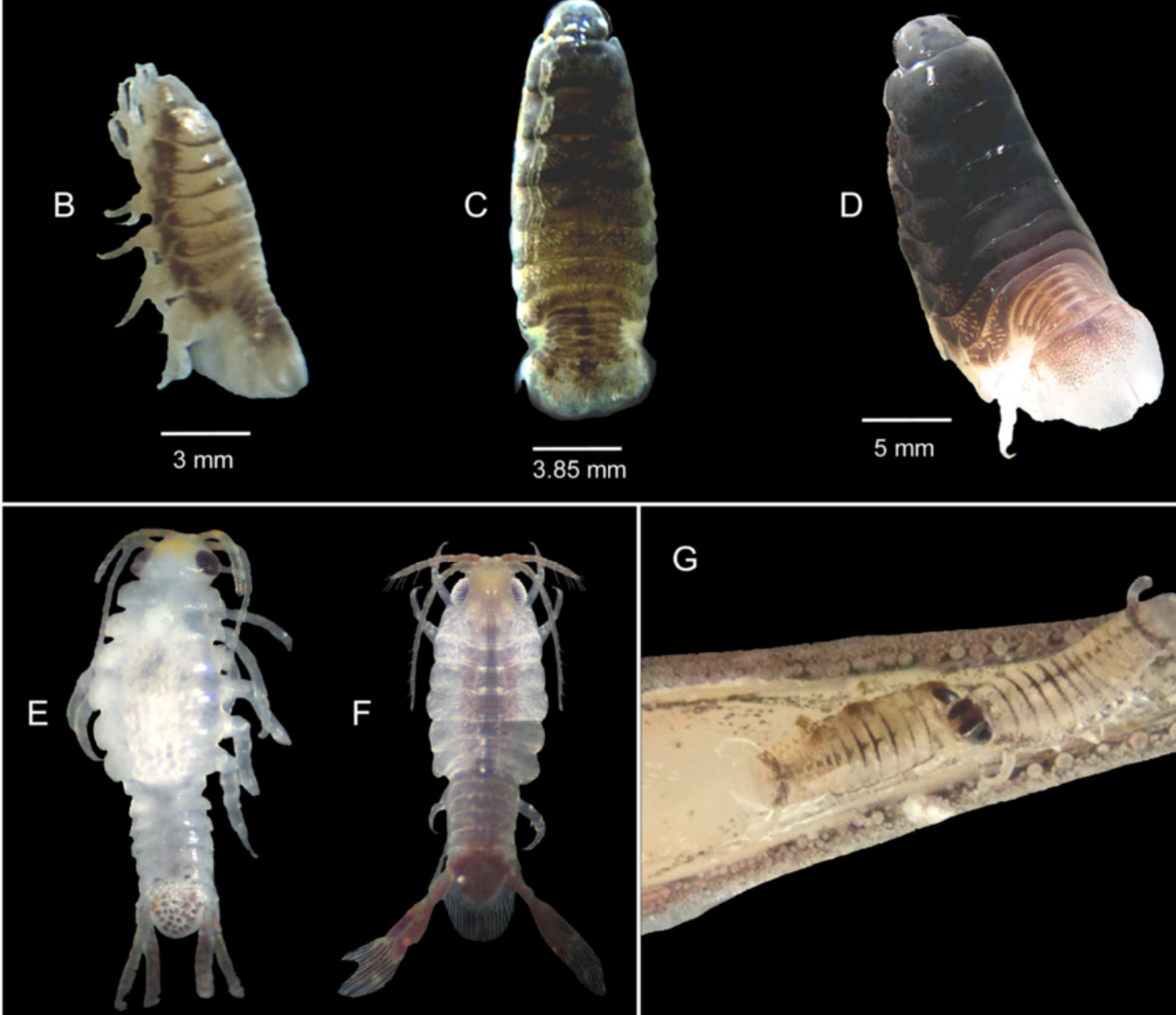

$0.5 \mathrm{~mm}$

F

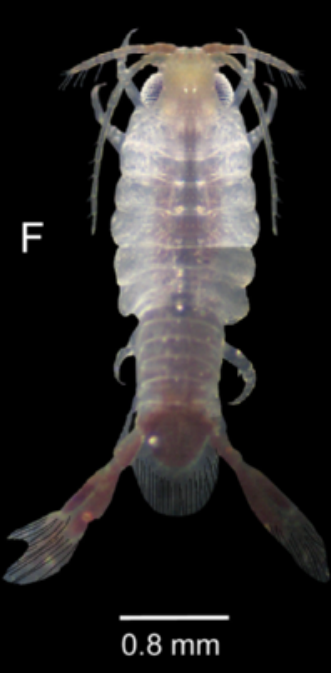

G

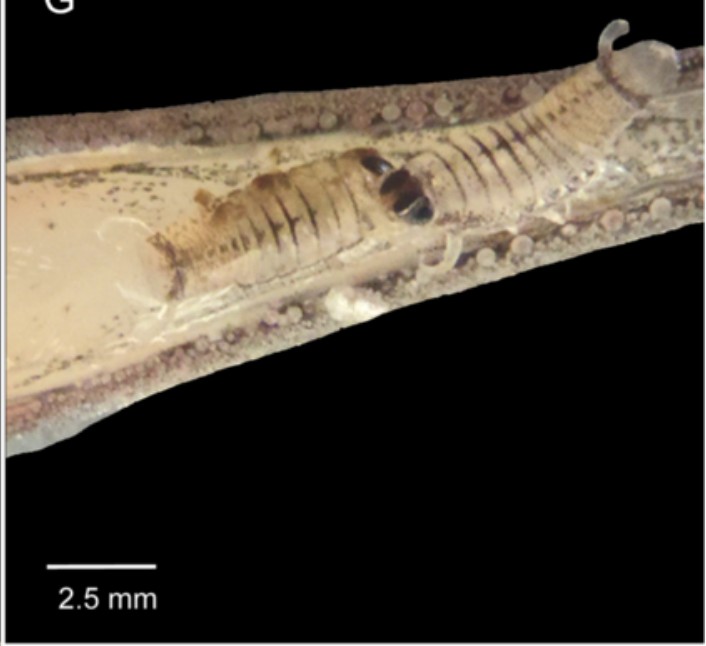

$\mathrm{H}$
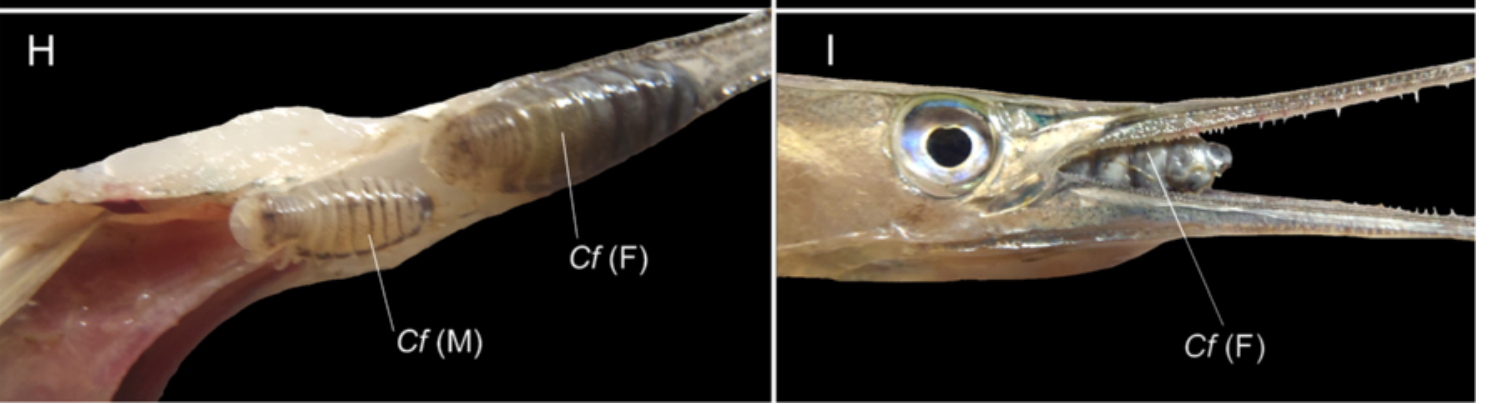

Figure 1 Cymothoa frontalis. (A) Host fish Strongylura strongylura. (B) Male. (C) Transitional. (D) Female. (E) Pre-manca. (F) Manca. (G) Juveniles on lower beak of the host fish S. strongylura. (H, I) C. frontalis on S. strongylura (Cf (M), Cymothoa frontalis male; Cf (F), Cymothoa frontalis female). 

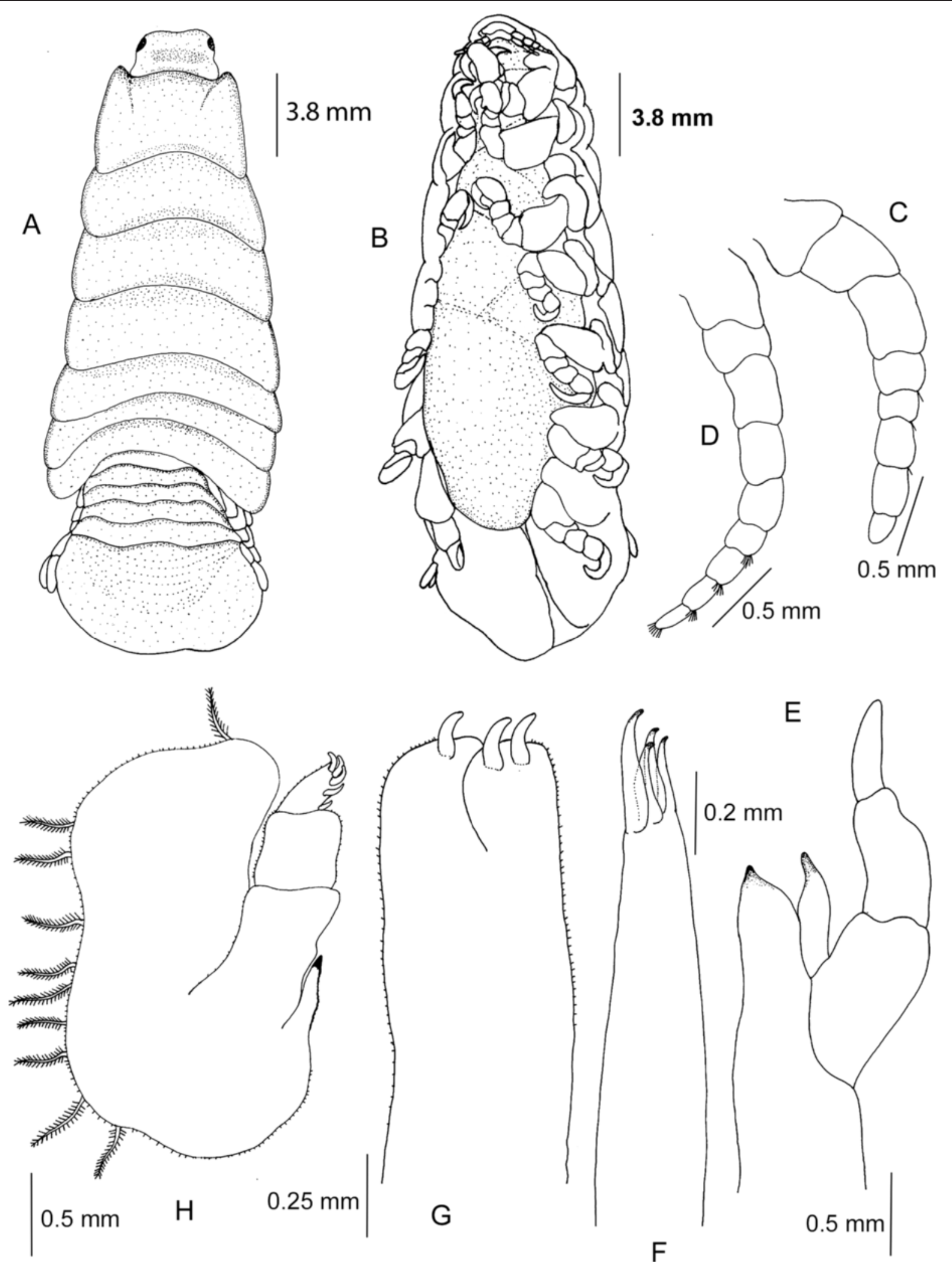

Figure 2 Cymothoa frontalis ovigerous female. (A) Dorsal view. (B) Ventral view. (C) Antennule. (D) Antenna. (E) Mandible. (F) Maxillule. (G) Maxilla. (H) Maxilliped. 


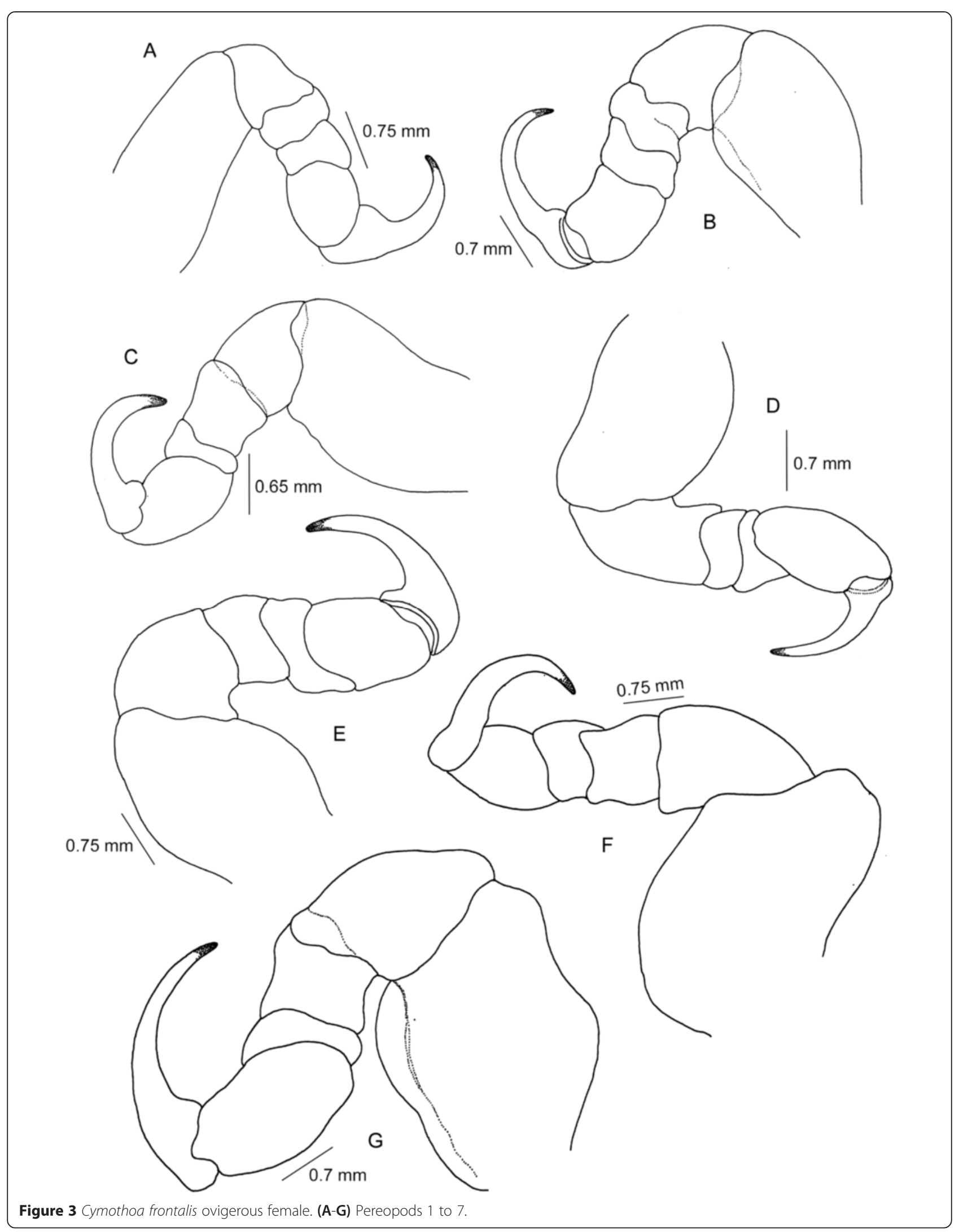




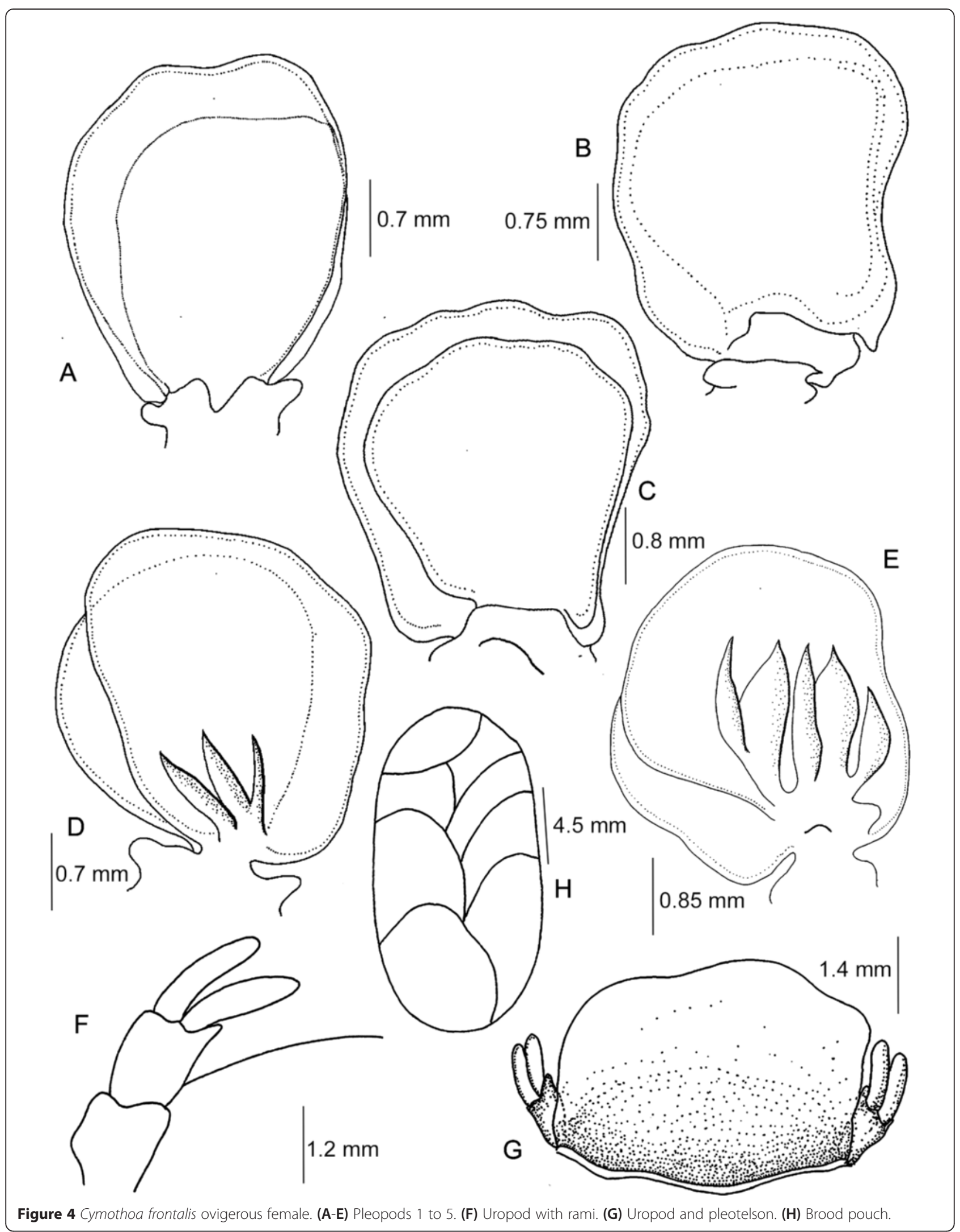




\begin{tabular}{|c|c|c|c|c|c|c|}
\hline Characteristics & Ovigerous female & Male & Transitional stage & Juvenile & Manca & Pre-manca \\
\hline Colour & $\begin{array}{l}\text { Light grey with highly } \\
\text { pigmented dorsal surface }\end{array}$ & $\begin{array}{l}\text { Creamy white with a pigmented } \\
\text { lateral and posterior margin of } \\
\text { pereonites }\end{array}$ & $\begin{array}{l}\text { Similar to that of ovigerous } \\
\text { female in late stage }\end{array}$ & $\begin{array}{l}\text { Transparent with scattered } \\
\text { chromatophores }\end{array}$ & $\begin{array}{l}\text { Clear with scattered } \\
\text { chromatophores } \\
\text { particularly on uropods } \\
\text { and pleotelson }\end{array}$ & Similar to that of manca \\
\hline $\begin{array}{l}\text { Site of } \\
\text { infestation }\end{array}$ & $\begin{array}{l}\text { On the floor of the buccal } \\
\text { cavity, the cephalon facing } \\
\text { the opening of the host } \\
\text { mouth }\end{array}$ & $\begin{array}{l}\text { On the floor of the buccal cavity, } \\
\text { on gill arch just behind the } \\
\text { female }\end{array}$ & Similar to that of female & $\begin{array}{l}\text { Usually in pairs, attached } \\
\text { on the lower mucous } \\
\text { membrane of the beak of } \\
\text { the host }\end{array}$ & $\begin{array}{l}\text { Found in the brood, } \\
\text { then released in to } \\
\text { water at inter-moult } \\
\text { stage and lead a short } \\
\text { free swimming life, and } \\
\text { finally the manca either } \\
\text { attaches to the body } \\
\text { surface of the specific } \\
\text { host or may die }\end{array}$ & $\begin{array}{l}\text { Seen with in the brood } \\
\text { pouch }\end{array}$ \\
\hline Size & $\begin{array}{l}2.6 \text { times as long as wide. } \\
\text { Widest at pereonites } 5 \text { to } 6\end{array}$ & Body 2.67 times as long as wide & Body 2.7 times as long as wide & $\begin{array}{l}\text { Body approximately } 3 \text { times } \\
\text { as long as wide }\end{array}$ & $\begin{array}{l}\text { Body } 3.5 \text { times as long } \\
\text { as wide }\end{array}$ & $\begin{array}{l}\text { Body } 4 \text { times as long as } \\
\text { wide }\end{array}$ \\
\hline Cephalon & $\begin{array}{l}\text { Partially immersed in poorly } \\
\text { developed amphicephalic } \\
\text { processes of pereonite 1, as } \\
\text { long as wide }\end{array}$ & $\begin{array}{l}\text { Cephalon not immersed in } \\
\text { pereonite } 1\end{array}$ & $\begin{array}{l}\text { Cephalon partially immersed } \\
\text { in poorly developed } \\
\text { amphicephalic processes of } \\
\text { pereonite } 1 \text {, as long as wide, } \\
\text { anterior margin truncate }\end{array}$ & $\begin{array}{l}\text { Anterior margin of } \\
\text { cephalon rounded, not } \\
\text { immersed in pereonite } 1\end{array}$ & $\begin{array}{l}\text { Cephalon wider than } \\
\text { long, } 1.6 \text { times as wide } \\
\text { as long and golden } \\
\text { yellow in colour }\end{array}$ & $\begin{array}{l}\text { Cephalon } 1.4 \text { times as } \\
\text { wider than long and not } \\
\text { immersed in pereonite } 1\end{array}$ \\
\hline Pereon & $\begin{array}{l}\text { With } 7 \text { pereonites. Coxae } \\
\text { not visible in dorsal view }\end{array}$ & $\begin{array}{l}\text { With } 7 \text { pereonites Coxae not } \\
\text { visible in dorsal view }\end{array}$ & $\begin{array}{l}\text { With } 7 \text { pereonites. Coxae not } \\
\text { visible in dorsal view }\end{array}$ & $\begin{array}{l}\text { With } 7 \text { pereonites. Coxae } \\
\text { not visible in dorsal view }\end{array}$ & $\begin{array}{l}\text { With } 7 \text { pereonites. } \\
\text { Coxae not visible in } \\
\text { dorsal view }\end{array}$ & $\begin{array}{l}\text { With } 7 \text { pereonites. Coxae } \\
\text { not visible in dorsal view }\end{array}$ \\
\hline Pleon & With 5 pleonites & With 5 pleonites & With 5 pleonites & With 5 pleonites & With 5 pleonites & With 5 pleonites \\
\hline Pleotelson & $\begin{array}{l}\text { Pleotelson } 1.6 \text { times as } \\
\text { wide as long, wider than } \\
\text { pleonite } 5, \text { posterior margin } \\
\text { broadly rounded }\end{array}$ & $\begin{array}{l}\text { Pleotelson } 2 \text { times as wide as } \\
\text { long, wider than pleonite } 5 \\
\text { posterior margin broadly rounded }\end{array}$ & $\begin{array}{l}\text { Pleotelson } 1.8 \text { to } 2 \text { times as } \\
\text { wide as long }\end{array}$ & $\begin{array}{l}\text { Pleotelson as long as wide, } \\
\text { apical margin rounded with } \\
\text { many setae }\end{array}$ & $\begin{array}{l}\text { Pleotelson } 1.2 \text { times as } \\
\text { wide as long and the } \\
\text { apical margin with } 18 \text { to } \\
20 \text { plumose setae }\end{array}$ & $\begin{array}{l}\text { Apical margin without } \\
\text { setae, dark pigmentation }\end{array}$ \\
\hline Eye & $\begin{array}{l}\text { Eyes small, not very } \\
\text { developed but moderately } \\
\text { distinct }\end{array}$ & $\begin{array}{l}\text { Eyes small, much prominent than } \\
\text { that of female }\end{array}$ & $\begin{array}{l}\text { Eyes small and moderately } \\
\text { distinct }\end{array}$ & $\begin{array}{l}\text { Eyes prominent, ovate and } \\
\text { conspicuous in dorsal view }\end{array}$ & $\begin{array}{l}\text { Eyes black, prominent, } \\
\text { ovate and conspicuous } \\
\text { in dorsal view }\end{array}$ & $\begin{array}{l}\text { Eyes black, prominent, } \\
\text { ovate and conspicuous in } \\
\text { dorsal view }\end{array}$ \\
\hline Antennule & $\begin{array}{l}\text { Antennule, stouter than } \\
\text { antenna, subequal in } \\
\text { length to antenna, } \\
\text { composed of } 8 \text { articles; } \\
\text { articles } 1 \text { to } 3 \text { slightly wider } \\
\text { than others }\end{array}$ & $\begin{array}{l}\text { Antennule, stouter than antenna, } \\
\text { subequal in length to antenna, } 8 \\
\text { articled; first three articles slightly } \\
\text { wider than other }\end{array}$ & $\begin{array}{l}\text { Similar to that of ovigerous } \\
\text { female }\end{array}$ & $\begin{array}{l}\text { Antennule } 8 \text { articled, } \\
\text { extending to anterior } \\
\text { margin of pereonite } 1 \text {; } \\
\text { articles } 5 \text { to } 8 \text { with } 3 \text { to } 5 \\
\text { spinules and article } 8 \text { with } \\
\text { few terminal aesthetascs }\end{array}$ & $\begin{array}{l}\text { Antennule, } 8 \text { articled, } \\
\text { extending to anterior } \\
\text { margin of pereonite 2; } \\
\text { article } 5,7 \text { and } 8 \text { with } 2 \\
\text { setae and article } 6 \text { with } \\
\text { one seta. All the articles } \\
\text { with } 3 \text { to } 4 \text { spinules and } \\
\text { article } 8 \text { with four } \\
\text { terminal aesthetascs }\end{array}$ & $\begin{array}{l}8 \text { articled antennules } \\
\text { smaller than antennae. } \\
\text { Without setae and } \\
\text { spinnules }\end{array}$ \\
\hline Antenna & $\begin{array}{l}\text { Antenna } 9 \text { articled, } \\
\text { decreasing gradually in } \\
\text { width, distal margin of } \\
\text { articles } 6,7 \text { and } 8 \text { with } 3 \text { to }\end{array}$ & $\begin{array}{l}\text { Antenna } 9 \text { articled, decreasing } \\
\text { gradually in width, distal margin } \\
\text { of articles } 6,7 \text { and } 8 \text { with } 3 \text { to } 6 \\
\text { setae; article } 9 \text { with } 3 \text { to } 6 \\
\text { terminal aesthetascs }\end{array}$ & $\begin{array}{l}\text { Similar to that of ovigerous } \\
\text { female }\end{array}$ & $\begin{array}{l}\text { Antenna longer than } \\
\text { antennule, } 9 \text { articled, } \\
\text { extending to anterior } \\
\text { margin of pereonite 2; } \\
\text { articles } 6 \text { to } 9 \text { with few }\end{array}$ & $\begin{array}{l}\text { Antenna longer than } \\
\text { antennules, } 11 \text { articled, } \\
\text { extending to anterior } \\
\text { margin of pereonite } 4 ; \\
\text { all the articles with }\end{array}$ & $\begin{array}{l}\text { Antenna is larger than } \\
\text { antennule and } 11 \text { articled. } \\
\text { Without setae and } \\
\text { spinnules }\end{array}$ \\
\hline
\end{tabular}


Table 1 Morphological characteristics of the different stages of the life cycle of Cymothoa frontalis (Continued)

\begin{tabular}{|c|c|c|c|c|c|c|}
\hline & $\begin{array}{l}6 \text { setae; article } 9 \text { with } 3 \\
\text { terminal aesthetascs }\end{array}$ & & & $\begin{array}{l}\text { spinnules, inner margin of } \\
\text { article } 3 \text { with } 4 \text {, article } 4 \\
\text { with } 5 \text { and terminal of } \\
\text { article and } 9 \text { with } 3 \text { setae; } \\
\text { distal margin of article } 4 \\
\text { and } 5 \text { with } 1 \text { plumose setae }\end{array}$ & $\begin{array}{l}\text { spinnules and article } 11 \\
\text { with } 4 \text { terminal } \\
\text { aesthetascs. Inner } \\
\text { margin of article } 3 \text { with } \\
1 \text { plumose seta }\end{array}$ & \\
\hline Mandible & $\begin{array}{l}\text { Mandible palp } 3 \\
\text { segmented, without setae }\end{array}$ & $\begin{array}{l}\text { Mandible palp } 3 \text { segmented, } \\
\text { articles } 2 \text { and } 3 \text { with several setae } \\
\text { on distolateral margin }\end{array}$ & Similar to that of male & $\begin{array}{l}\text { Mandible palp article } 2 \\
\text { with } 4 \text { to } 6 \text { marginal seta; } \\
\text { article } 3 \text { with } 5 \text { to } 8 \\
\text { marginal setae and } 1 \text { apical } \\
\text { recurved seta }\end{array}$ & $\begin{array}{l}\text { Mandible palp article } 2 \\
\text { with } 1 \text { seta arising from } \\
\text { the distal margin; article } \\
3 \text { with } 3 \text { marginal setae } \\
\text { and } 1 \text { apical recurved } \\
\text { seta }\end{array}$ & $\begin{array}{l}\text { Not well developed. Palp } \\
\text { without setae }\end{array}$ \\
\hline Maxilla & $\begin{array}{l}\text { With } 2 \text { spines on median } \\
\text { lobe and } 1 \text { spine on lateral } \\
\text { lobe }\end{array}$ & $\begin{array}{l}\text { Bi-lobed, with } 2 \text { spines on median } \\
\text { and lateral lobes }\end{array}$ & Similar to that of male & Similar to male stage & Similar to male stage & Not well developed \\
\hline Maxillule & $\begin{array}{l}\text { With } 4 \text { apical spines, } \\
\text { slightly recurved }\end{array}$ & $\begin{array}{l}\text { With } 4 \text { apical spines, slightly } \\
\text { recurved }\end{array}$ & $\begin{array}{l}\text { With } 4 \text { apical spines, slightly } \\
\text { recurved }\end{array}$ & Similar to male stage & Similar to male & Not well developed \\
\hline Maxilliped & $\begin{array}{l}\text { Maxilliped with oostegial } \\
\text { lobes with many plumose } \\
\text { setae and a palp with } 3 \\
\text { small apical and } 2 \text { lateral } \\
\text { recurved spines on article } 3\end{array}$ & $\begin{array}{l}\text { Without oostegial lobes and } 5 \\
\text { apical recurved spines on article } 3 \\
\text { of palp }\end{array}$ & Similar to that of male & Similar to male stage & Similar to that of male & Not well developed \\
\hline Pereopods & $\begin{array}{l}\text { Gradually increased in size } \\
\text { from } 1 \text { to } 7 \text {, without spines; } \\
\text { broad basis increasing in } \\
\text { width progressively from } \\
\text { p1-p7 }\end{array}$ & $\begin{array}{l}\text { Pereopods } 1 \text { to } 7 \text { gradually } \\
\text { increased in size, without spines; } \\
\text { basis increasing in width } \\
\text { progressively }\end{array}$ & $\begin{array}{l}\text { Similar to that of ovigerous } \\
\text { female }\end{array}$ & $\begin{array}{l}\text { Pereopod } 1 \text { without spines, } \\
\text { pereopods } 2 \text { to } 5 \text { with } 1 \text { to } \\
2 \text { spines on posterior } \\
\text { margin of propodus; } \\
\text { pereopod } 3 \text { and } 5 \text { with } 1 \\
\text { spine on the posterior } \\
\text { margin of merus and the } \\
\text { vestigial pereopod } 7 \text { with } 3 \\
\text { to } 4 \text { spines on carpus and } 4 \\
\text { to } 6 \text { spines on propodus. } \\
\text { Pereopods } 1 \text { to } 3 \text {, dactylus } \\
\text { with vestigial teeth; } \\
\text { dactylus of pereopods } 2 \\
\text { and } 3 \text {, about } 2 \text { times longer } \\
\text { than propodus, pereopod } 7 \\
\text { with short and blunt } \\
\text { dactylus }\end{array}$ & $\begin{array}{l}6 \text { pereopods; pereopod } \\
1 \text {, with } 1 \text { spine on } \\
\text { merus and carpus. } \\
\text { Pereopod } 2 \text { with } 1 \text { spine } \\
\text { on posterior margin of } \\
\text { merus; pereopod } 3 \text { with } \\
1 \text { spine on the posterior } \\
\text { margin of merus and } \\
\text { propodus. One spine on } \\
\text { the posterior margin of } \\
\text { propodus of pereopod } \\
4 ; \text { pereopod } 5 \text { and } 6 \\
\text { with } 1 \text { spine on carpus } \\
\text { and } 2 \text { to } 3 \text { spines on the } \\
\text { posterior margin of } \\
\text { propodus. Dactyls of } \\
\text { pereopods } 1 \text { to } 3 \\
\text { toothed, } 4 \text { to } 6 \text { not } \\
\text { toothed }\end{array}$ & $\begin{array}{l}\text { Only } 6 \text { pereopods. } \\
\text { Pereopod } 7 \text { is missing. } \\
\text { Without spines }\end{array}$ \\
\hline Penes & Absent & Penes visibles on sternite 7 & $\begin{array}{l}\text { Rudimentary penes visible on } \\
\text { sternite } 7\end{array}$ & $\begin{array}{l}\text { Poorly developed penes on } \\
\text { sternite } 7\end{array}$ & Absent & Absent \\
\hline Brood pouch & $\begin{array}{l}\text { Brood pouch made up of } 4 \\
\text { pairs of overlapping } \\
\text { oostegites arising from the } \\
\text { bases of pereopods } 2,3,4 \\
\text { and } 6\end{array}$ & - & - & - & - & \\
\hline
\end{tabular}


Table 1 Morphological characteristics of the different stages of the life cycle of Cymothoa frontalis (Continued)

\begin{tabular}{|c|c|c|c|c|c|c|}
\hline Pleopods & $\begin{array}{l}\text { Pleopods not distinctly } \\
\text { visible in dorsal view. } \\
\text { Pleopod } 2 \text { without } \\
\text { appendix masculine. } \\
\text { Endopods of pleopods } 4 \\
\text { and } 5 \text { moderately or } \\
\text { strongly folded, respectively }\end{array}$ & $\begin{array}{l}\text { Pleopods not distinctly visible in } \\
\text { dorsal view. Pleopod } 2 \text { with } \\
\text { appendix masculine. Endopodite } \\
\text { of pleopods } 4 \text { and } 5 \text { moderately } \\
\text { or strongly folded }\end{array}$ & $\begin{array}{l}\text { Pleopod } 2 \text { with appendix } \\
\text { masculina like that of male }\end{array}$ & $\begin{array}{l}\text { The lateral margin of } \\
\text { exopodite of all pleopods } \\
\text { with few setae and the } \\
\text { median margin of } \\
\text { protopod with } 4 / 5 \\
\text { retinaculae. Pleopod } 2 \text { with } \\
\text { thick and vestigial appendix } \\
\text { masculina, as long as } \\
\text { endopodite. Pleopods } 1 \\
\text { and } 3 \text { subequal. Endopods } \\
\text { of pleopods } 4 \text { and } 5 \\
\text { moderately folded }\end{array}$ & $\begin{array}{l}\text { Pleopods not distinctly } \\
\text { visible in dorsal view. } \\
\text { Pleopod } 1 \text { with } 4 \text { to } 6 \\
\text { plumose setae on } \\
\text { endopodite and } 14 \text { to } \\
18 \text { plumose setae on } \\
\text { exopodite. Pleopods } 2 \\
\text { to } 5 \text {, apical margin of } \\
\text { exopodite with } 14 \text { to } 18 \\
\text { plumose setae }\end{array}$ & $\begin{array}{l}\text { Exopodite without } \\
\text { plumose setae. appendix } \\
\text { masculine not developed }\end{array}$ \\
\hline Uropods & $\begin{array}{l}\text { Uropod rami short, not } \\
\text { reaching the distal margin } \\
\text { of pleotelson; rami } \\
\text { subequal in length, curved } \\
\text { and apically rounded }\end{array}$ & $\begin{array}{l}\text { Uropod rami short, not reaching } \\
\text { the distal margin of pleotelson; } \\
\text { rami subequal in length, curved } \\
\text { and apically rounded }\end{array}$ & $\begin{array}{l}\text { Pleotelson } 1.8 \text { to } 2 \text { times as } \\
\text { wide as long and uropods } \\
\text { similar to those of ovigerous } \\
\text { female }\end{array}$ & $\begin{array}{l}\text { Pleotelson as long as wide, } \\
\text { apical margin rounded with } \\
\text { many setae. Uropods } \\
\text { extending beyond the } \\
\text { distal margin of pleotelson, } \\
\text { inner margin of basis with } \\
3 \text { to } 4 \text { plumose setae; rami } \\
\text { subequal in length but } \\
\text { exopodite slightly shortest, } \\
\text { curved and apically round; } \\
\text { exopodite with } 40 \text { to } 44 \text {, } \\
\text { and the endopodite with } \\
60 \text { to } 64 \text { setae }\end{array}$ & $\begin{array}{l}\text { Pleotelson } 1.2 \text { times as } \\
\text { wide as long and the } \\
\text { apical margin with } 18 \text { to } \\
20 \text { plumose setae. } \\
\text { Uropod basis extending } \\
\text { beyond the distal } \\
\text { margin of pleotelson; } \\
\text { rami subequal extending } \\
\text { strongly beyond the } \\
\text { distal margin of } \\
\text { pleotelson, apically } \\
\text { rounded with } 8 \text { to } 12 \\
\text { plumose setae. Uropods } \\
\text { and pleotelson with } \\
\text { many dark } \\
\text { chromatophores }\end{array}$ & $\begin{array}{l}\text { Uropods extending } \\
\text { beyond the pleotelson, } \\
\text { rami subequal; dark } \\
\text { pigmentation only on the } \\
\text { uropods and pleotelson }\end{array}$ \\
\hline
\end{tabular}




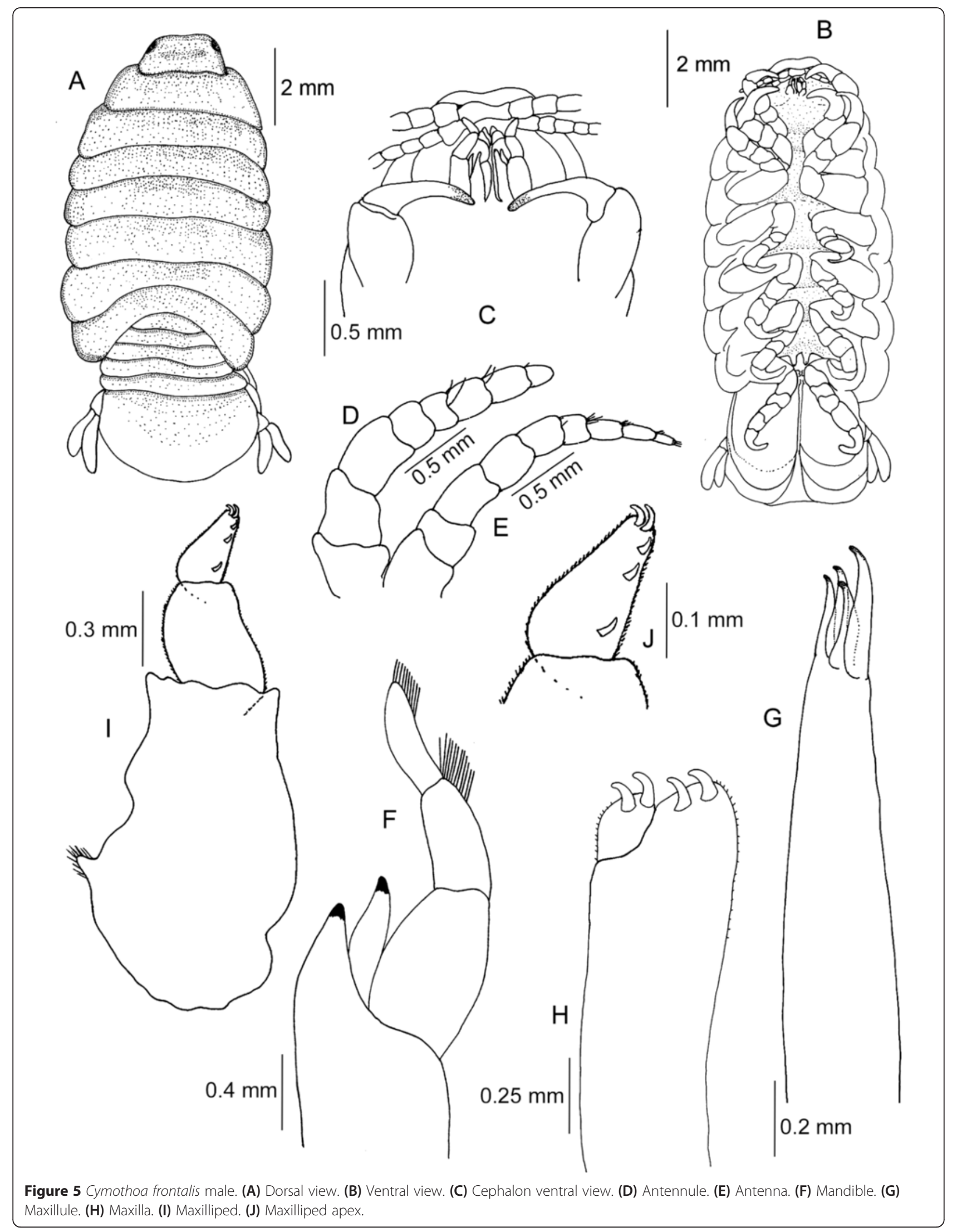




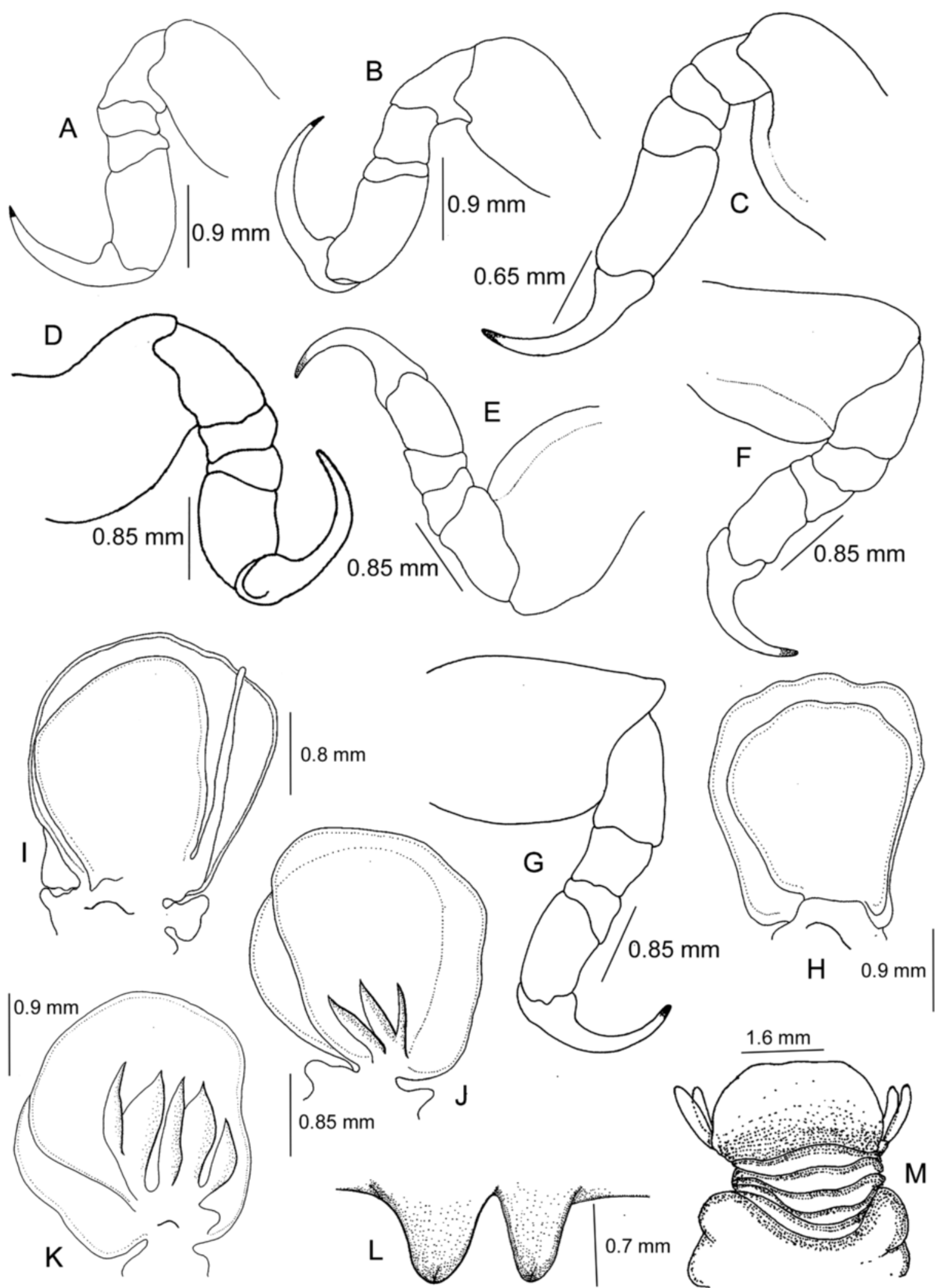

Figure 6 Cymothoa frontalis male. (A-G) Pereopods 1 to 7. (H) Pleopod 1. (I) Pleopod 2. (J) Pleopod 4. (K) Pleopod 5. (L) Penes. (M) Pleonites, pleotelson and uropods. 


\section{Description of the transitional stage}

Body 2.7 times as long as wide (Figures $1 \mathrm{C}$ and 7; Table 1); Eyes small and moderately distinct. Cephalon partially immersed in poorly developed amphicephalic process of pereonite 1 , as long as wide, anterior margin truncate.

Pereonites, pleonites, antennules, antenna and mandible palp are similar to those of the ovigerous female and maxilla, maxilliped similar to those of the male. Rudimentary penes are visible on sternite 7. Pleotelson 1.8 to 2 times as wide as long, slightly wider than pleonite 5 and uropods similar to those of the ovigerous female. Pereopods and pleopods similar to those of female and male.

\section{Description of the juvenile}

Body approximately 3 times as long as wide, relatively narrower and smaller than those of the female, transitional stage and male (Figures 1G, 8, 9 and 10; Table 1). Eyes prominent, ovate and conspicuous in dorsal view; anterior margin of cephalon rounded, not immersed in pereonite 1 . Pereonite 1 longest, pereonites 2, 3 and 4 subequal; pereonites 4 and 5 widest and subequal. Pereonites 5 to 7 gradually decreasing in length. Pleonites gradually decreasing in width towards posterior but subequal in length. Pleotelson as long as wide, apical margin rounded with many setae.

Antennule 8 articled, reaching the anterior margin of pereonite 1; articles 5 to 8 with 3 to 5 spinules and article 8 with few terminal aesthetascs. Antenna longer than antennule, 9 articled, extending to anterior margin of pereonite 2; articles 6 to 9 with few spinules, inner margin of articles 3 and 4 with 4 and 5 setae, respectively; distal margin of article 9 with 3 setae; articles 4 and 5 with 1 plumose setae. Article 2 of mandible palp with 4 to 6 marginal setae; third article with 5 to 8 marginal setae and one apical recurved seta. Maxillule, maxilla and maxilliped similar to those of the male stage.

Pereopod 1 without spines, pereopods 2 to 5 with 1 or 2 spines on posterior margin of propodus; pereopods 3 and 5 with 1 spine on the posterior margin of merus and the vestigial pereopod 7 with 3 to 4 spines on carpus

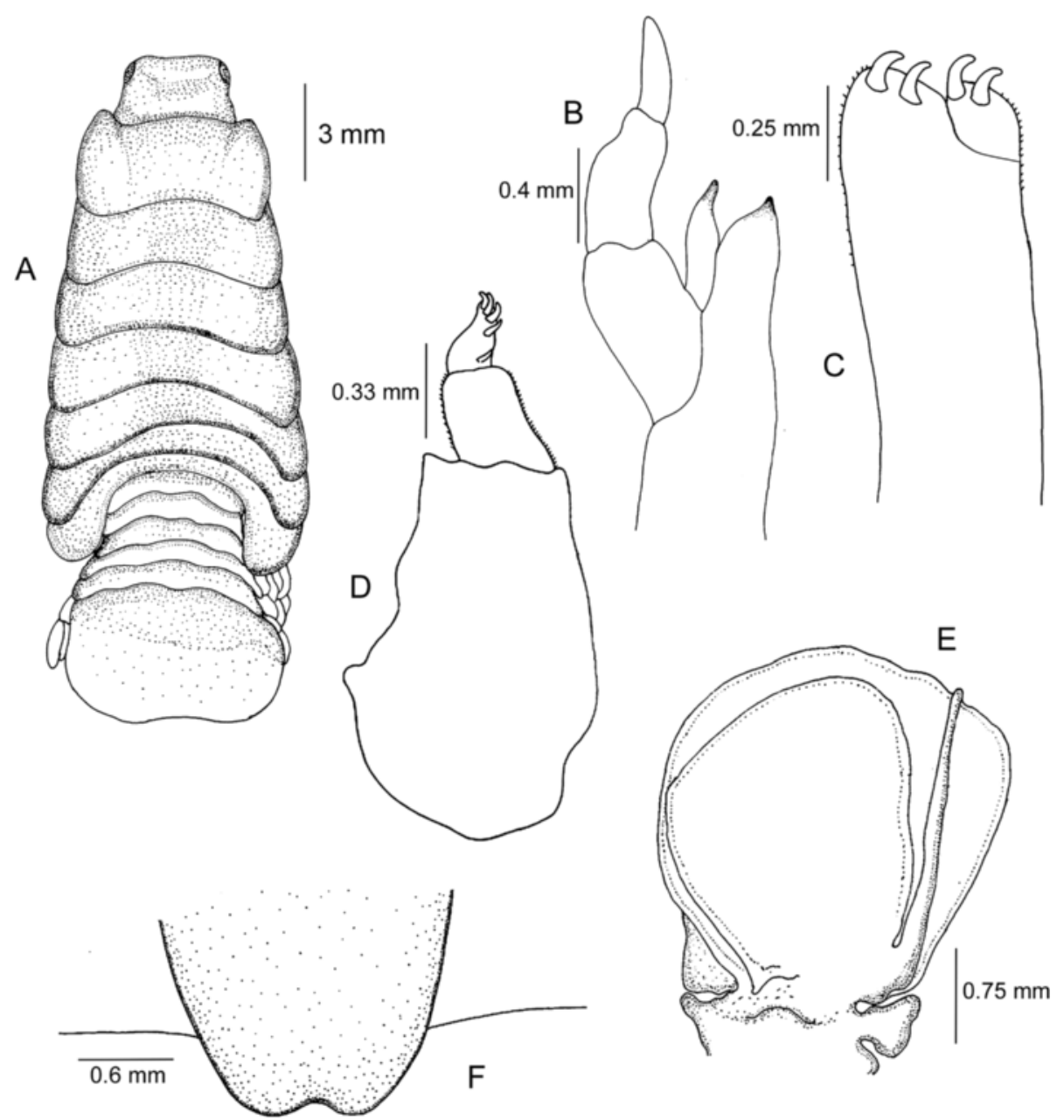

Figure 7 Cymothoa frontalis transitional stage. (A) Dorsal view. (B) Mandible. (C) Maxilla. (D) Maxilliped. (E) Pleopod 2. (F) Penes. 


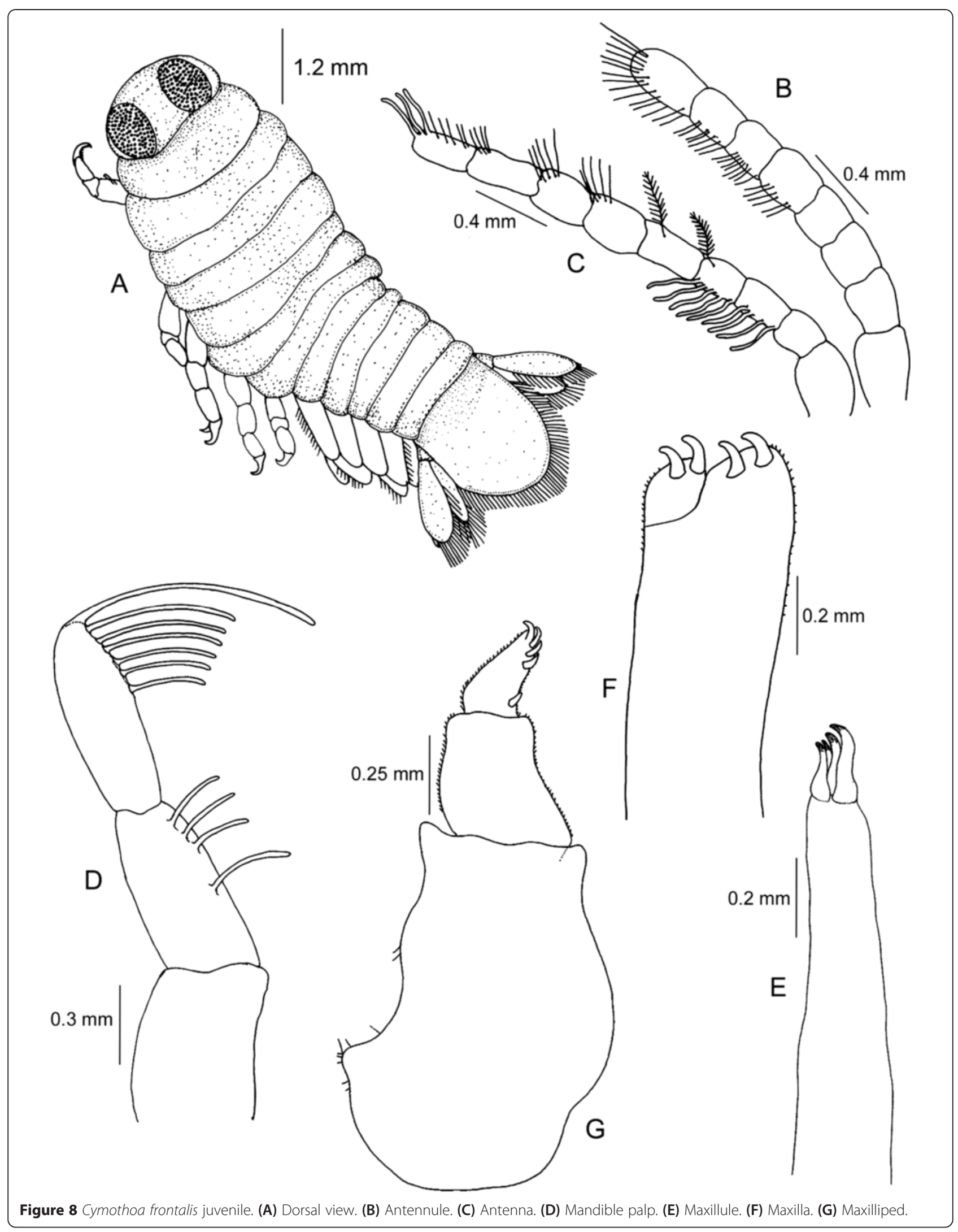




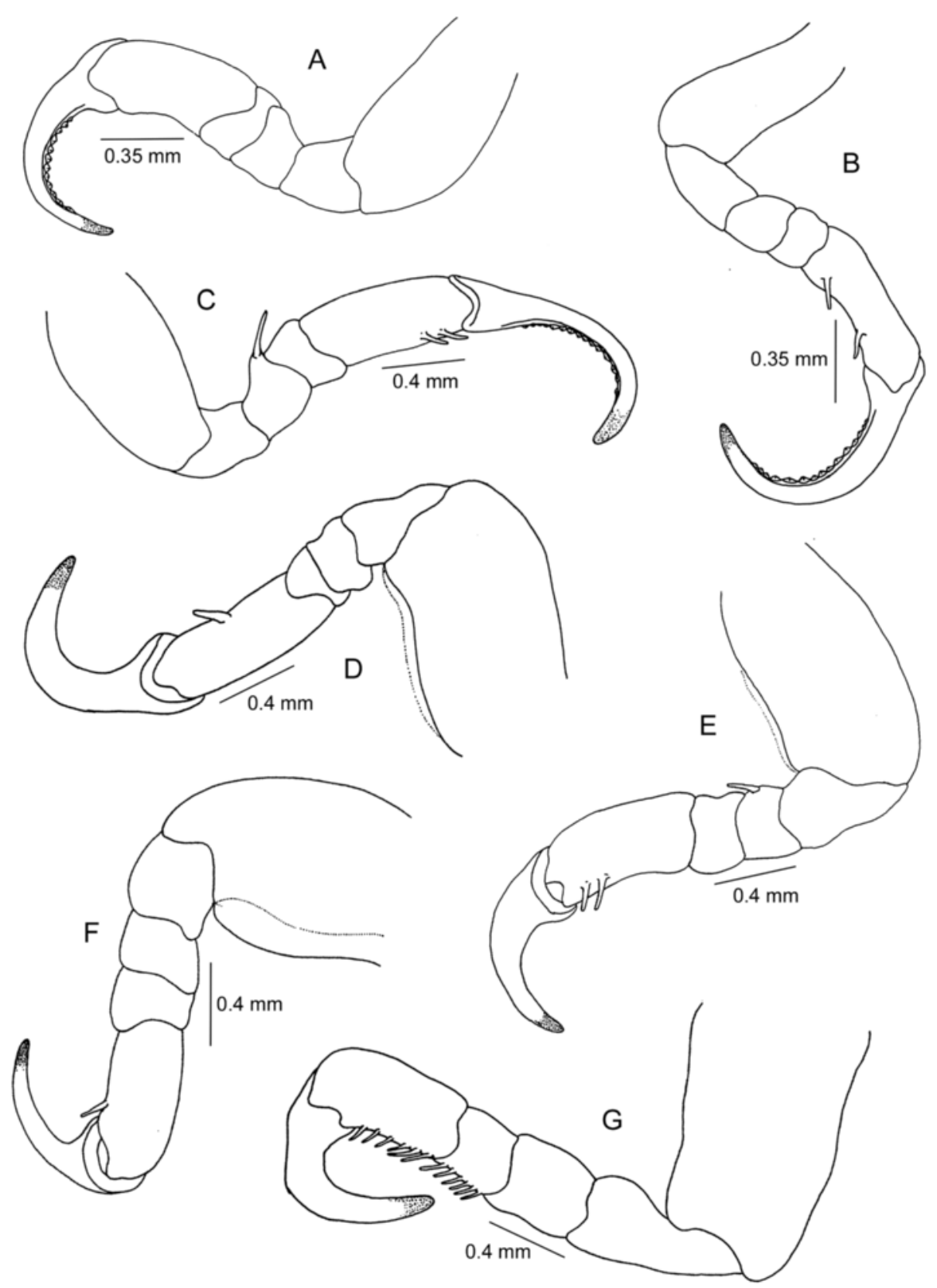

Figure 9 Cymothoa frontalis juvenile. (A-F) Pereopods 1 to 6. (G) Pereopod 7 with short and blunt dactylus.

and 4 to 6 spines on propodus. Pereopods 1 to 3 dactylus with vestigial teeth; dactylus of pereopods 2 and 3, about 2 times longer than propodus, pereopod 7 with short and blunt dactylus. Penes not developed. The lateral margin of exopodite of all pleopods with small setae, but not on the apical margin. Median margin of protopod with 4/5 retinaculae. Pleopod 2 with thick and vestigial appendix masculina, as long as endopodite. Pleopods 1 and 3 subequal. Endopod of pleopods 4 and 5 moderately folded. Uropod extending beyond the distal margin of pleotelson, inner margin of basis with 3 to 4 plumose setae; rami slightly curved, endopodite relatively large, exopodite with an apical recurved spine. Endopodite margin with 60 to 66 setae. Exopodite with 40 to 44 setae, restricted to the inner margin.

\section{Description of the manca}

The manca developed from the pre-manca through moulting shows distinct morphological characters (Figures 1F, 11 and 12; Table 1).

Body elongated and transparent, 3.5 times as long as wide, eyes black, prominent, ovate and conspicuous in 


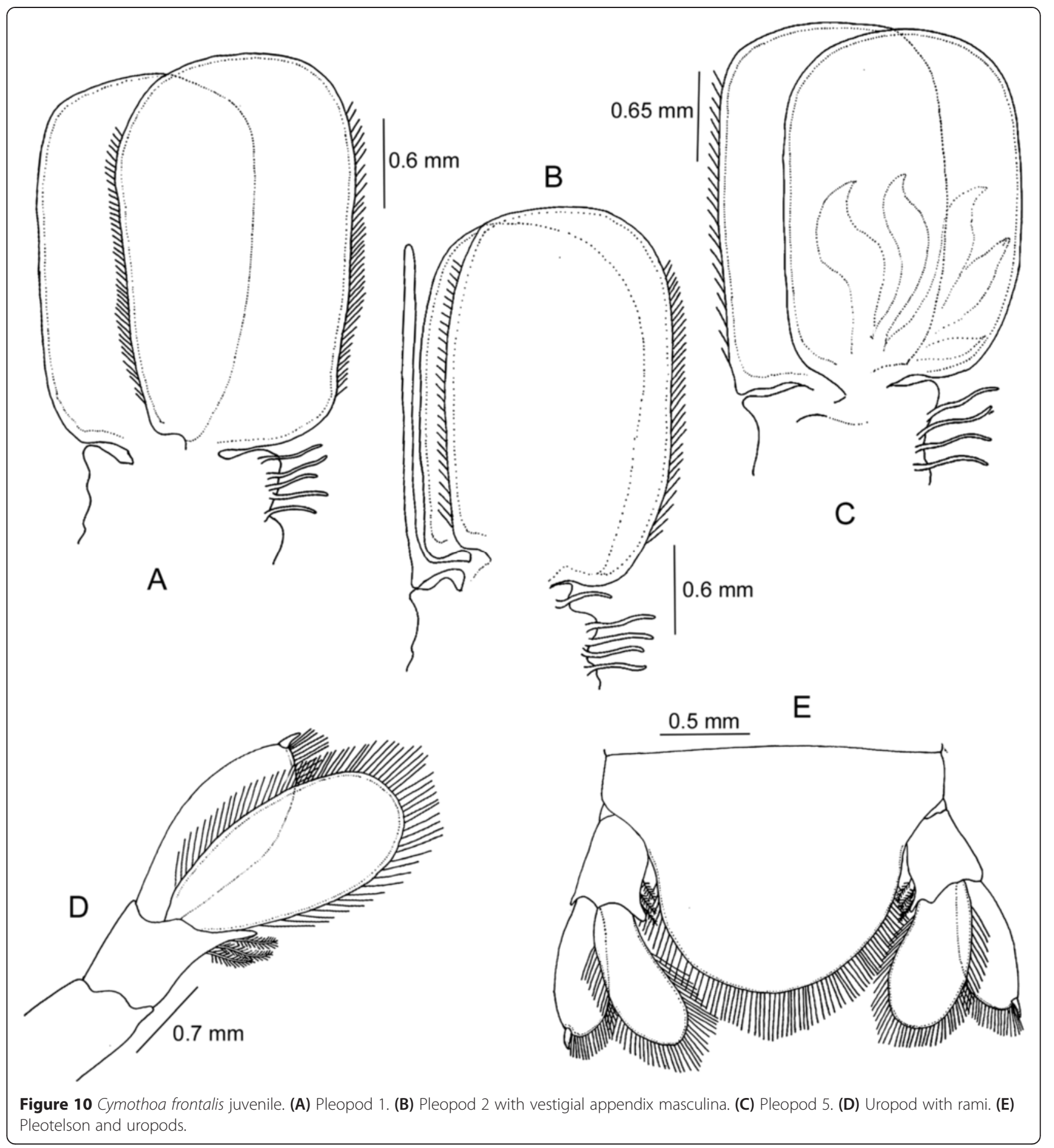

dorsal view. Cephalon 1.6 times as wide as long and golden yellow in colour.

Pereonite 1 relatively long; pereonites 2,3 and 4 subequal in length; longer than pereonites 5 and 6 ; pereonites 5 and 6 subequal in length; pereonite 7 short and narrow; pereonites 4 and 5 widest. All pleonites visible and subequal in width and length; 4.8 times as wide as long. Pleotelson 1.2 times as wide as long and the apical margin with 18 to 20 plumose setae.

Eight articled antennule extends to anterior margin of pereonite 2; articles 5, 7 and 8 each with 2 setae and article 6 with 1 seta; all the articles with 3 to 4 spinules and article 8 with 4 terminal aesthetascs. Antenna longer than antennule, 11 articled, extending to anterior margin 


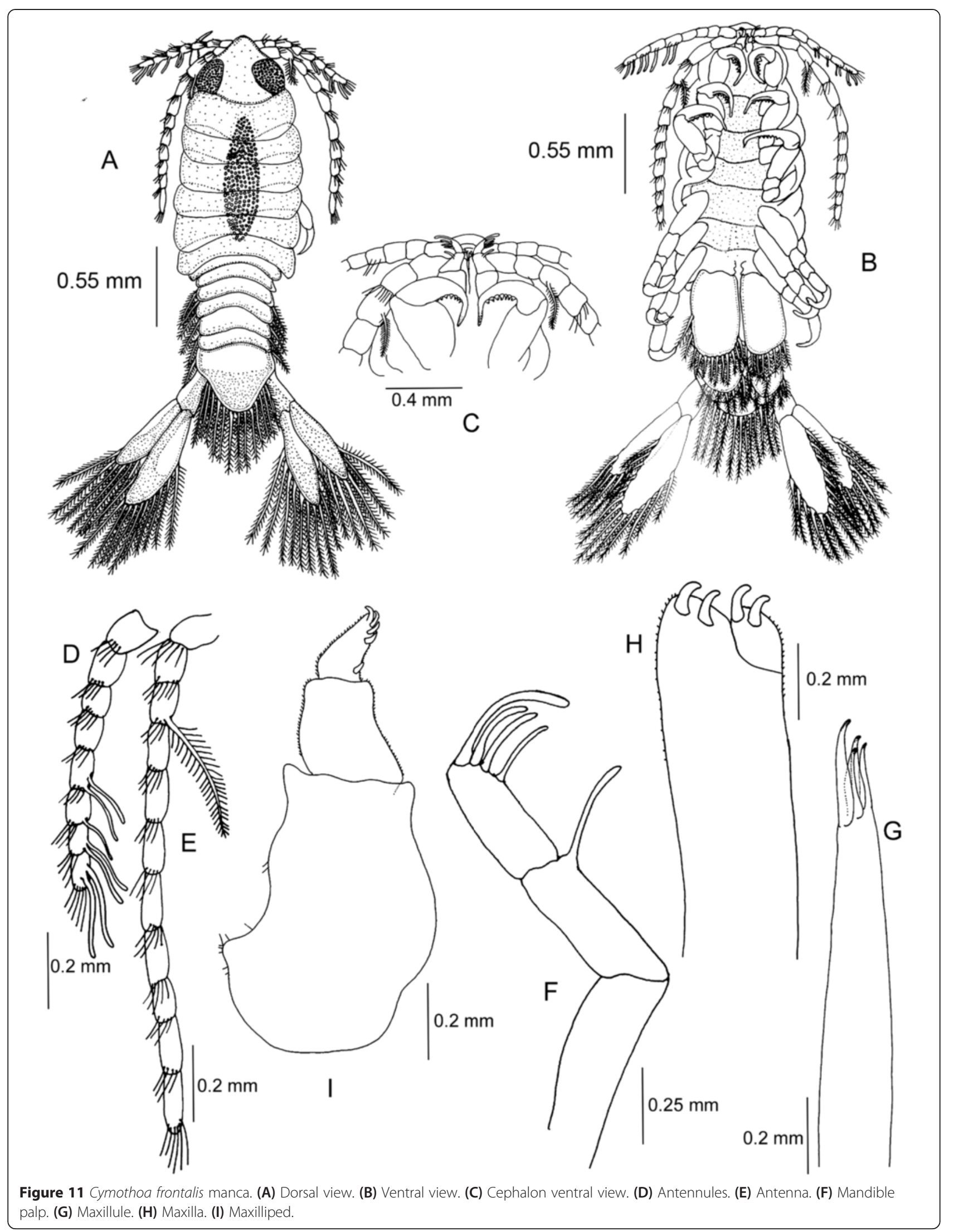




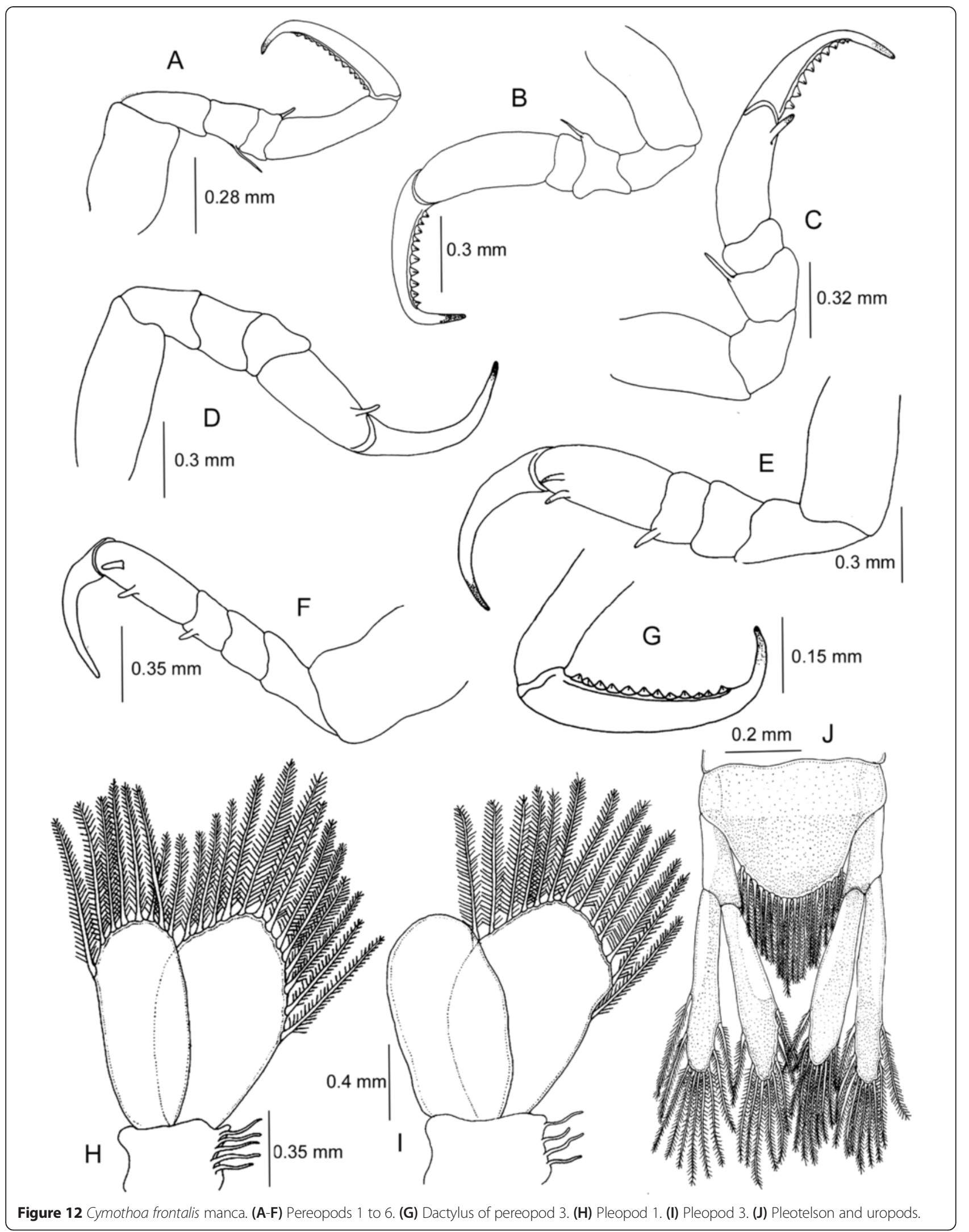


of pereonite 4; all the articles with spinules and article 11 with 4 terminal aesthetascs; inner margin of article 3 with 1 plumose seta. Article 2 of the mandible palp with 1 seta arising from the disto-lateral margin; article 3 with 3 marginal setae and 1 apical recurved seta. Maxillule, maxilla and maxilliped similar to those of the male stage.

Six pereopods; pereopod 1, with 1 spine on merus and carpus. Pereopod 2 with 1 spine on posterior margin of merus; pereopod 3 with 1 spine on the posterior margin of merus and propodus; 1 spine on the posterior margin of propodus of pereopod 4; pereopods 5 and 6 with 1 spine on carpus and 2 to 3 spines on the posterior margin of propodus. Dactyls of pereopods 1 to 3 toothed, 4 to 6 not toothed. Pleopods not distinctly visible in dorsal view. Pleopod 1 with 6 to 8 plumose setae on endopodite and 14 to 18 plumose setae on exopodite. Pleopods 2 to 5 , apical margin of exopodite with 14 to 18 plumose setae. Uropod rami subequal, extending strongly beyond the distal margin of pleotelson, apically rounded with 8 to 12 plumose setae. Uropods and pleotelson with many dark chromatophores.

\section{Description of the pre-manca}

Body elongated and transparent, 4 times as long as wide, eyes black, prominent, ovate and conspicuous in dorsal view (Figures 1E and 13; Table 1). Cephalon 1.4 times as wide as long, not immersed in pereonite 1. Yolk globules are visible in the pereon, between pereonites 2 and 6 . Pereonite 1 slightly long, pereonite 7 short and narrow. Pereonites 4 and 5 widest. All pleonites visible and subequal in width and length; 3.6 times as wide as long. Pleotelson as wide as long, without plumose setae.

Antenna larger than antennule. Eight articled antennule extends to anterior margin of pereonite 2; antenna longer than antennule, 11 articled, extending to anterior margin of pereonite 4; all articles without setae and spinules. Mouthparts are not well developed; mandible palp articles without setae and spines; maxillule, maxilla and maxilliped with poorly developed apical non-recurved spines.

Six pereopods; pereopods 1 to 6 without spines. Distal margin of dactylus of pereopod 1 to 6 slightly indented and then forming a narrow terminal part. Dactylus of pereopod not toothed. Pleopods not distinctly visible in dorsal view. Pleopods 1 to 5 without plumose setae. Uropod rami subequal, extending strongly beyond the distal margin of pleotelson, apically rounded without plumose setae. Uropods and pleotelson with dark chromatophores.

Size: Ovigerous females, 21 to $28 \mathrm{~mm}$; transitional stage, 15 to $23 \mathrm{~mm}$; male, 11 to $13 \mathrm{~mm}$; juvenile, 7 to $9 \mathrm{~mm}$; manca, 3 to $3.4 \mathrm{~mm}$; pre-manca, 2.2 to $2.4 \mathrm{~mm}$.

Host: Present Indian material is from S. strongylura (Van Hasselt 1823). Until now, a single specimen was doubtfully reported by White (1847), from a host belonging to the genus Cyclopterus.
Distribution: Asian Sea (Milne Edwards 1840) and Indian Ocean (White 1847); Singapore (Heller 1868) and Bangkok (Schioedte and Meinert 1884); Malabar Coast, Kerala, India (present study).

Colour: Female and transitional stage - light grey with highly pigmented dorsal surface; male - creamy white with a pigmented lateral and posterior margin of pereonites and pleonites; juvenile - transparent with scattered pigmentation throughout the body. Posterior margin and lateral side of pereonites and pleonites and anterior margin of pleotelson with lining chromatophores, Manca and pre-manca - clear with scattered chromatophores particularly on uropods and pleotelson; cephalon golden yellow in colour.

\section{Occurrence and prevalence of infestation by $C$. frontalis on S. strongylura}

Eighty species of fishes belonging to 35 families were examined from November 2009 to November 2012 for the presence of $C$. frontalis; however, this cymothoid was recovered only from the belonid fish $S$. strongylura, signifying its oligoxenous host specificity (Table 2).

Among 134 members of host fish (S. strongylura) examined, 92 were infested by $C$. frontalis, the prevalence being 68.65\%. A total of $171 \mathrm{C}$. frontalis including 67 ovigerous females, 14 transitional stages, 68 males and 22 juveniles were recovered; the mean intensity being equal to 1.9 (Table 3) (Figure 1B,C,D,E,F,G). Out of 92 infested members of S. strongylura, 79 were found with two members of $C$. frontalis appearing like a pair, but in three combinations such as male-female, maletransitional and juvenile-juvenile, with the male-female pair being predominant (56 out of 79); the large ovigerous female was attached on the floor of the buccal cavity, their cephalon facing towards the opening of the host mouth; male settled just behind the female on the gill arch (Figure 1A,G,H,I). In the case of the maletransitional pair (12 out of 79), both were found attached on the tongue of the host. The juvenile pair (11 out of 79) prefers the mucous membrane of the lower beak of the fish (Figure 1G). Unpaired females or transitional stages were also observed in 11 and 2 instances, respectively.

\section{Life cycle of $C$. frontalis}

The present study identified three major phases (such as marsupial, free living and infective) in the life cycle of $C$. frontalis. The details of each phase are represented in Table 4 and Figures 14 and 15. The marsupial phase encompasses one zygotic, three embryonic (ES I, ES II and ES III) and two larval (pre-manca and manca) stages, and each stage is found to be distinct from one another by their precise morphological characteristics (Figure 14). Round zygotic-staged eggs appear in light florescent 


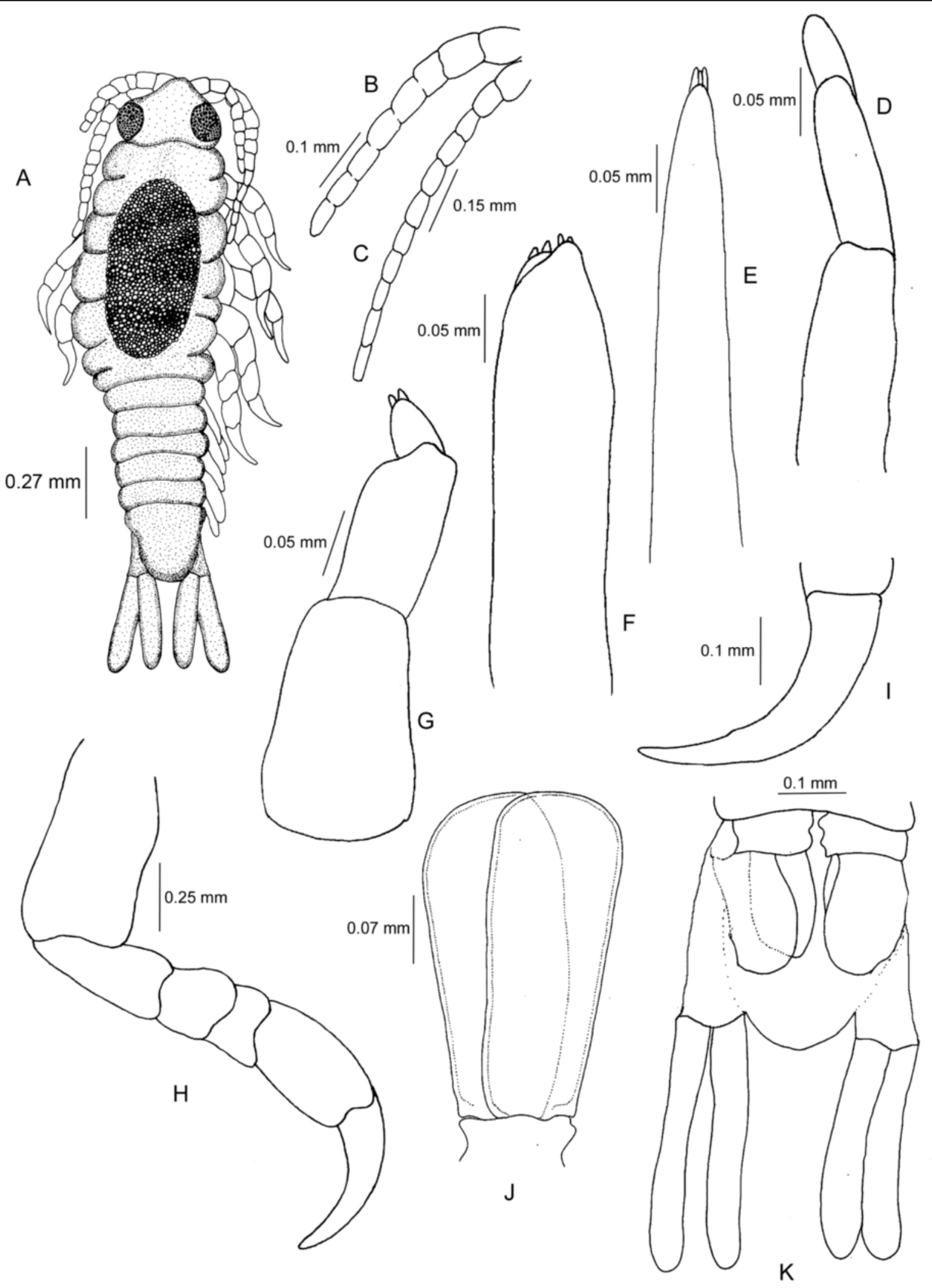

Figure 13 Cymothoa frontalis pre-manca. (A) Dorsal view. (B) Antennule. (C) Antenna. (D) Mandible palp. (E) Maxillule. (F) Maxilla. (G) Maxilliped. (H) Pereopod 3. (I) Dactylus of pereopod 3. (J) Pleopod 2. (K) Ventral view of pleotelson and uropods. 
Table 2 List of marine fishes examined from Malabar Coast, India, during the period from November 2009 to November 2012

\begin{tabular}{|c|c|c|c|c|}
\hline $\begin{array}{l}\text { Serial } \\
\text { number }\end{array}$ & Family & Fish species & $\begin{array}{l}\text { Number of fishes } \\
\text { examined }\end{array}$ & $\begin{array}{l}\text { Infestation by Cymothoa } \\
\text { frontalis }\end{array}$ \\
\hline \multirow[t]{5}{*}{1} & Scombridae & Rastrelliger kanagurta (Cuvier, 1817) & 1,329 & - \\
\hline & & Thunnus obesus (Lowe, 1839) & 69 & - \\
\hline & & Scomberomorus guttatus (Bloch and Schneider, 1801) & 323 & - \\
\hline & & Scomberomorus commerson (Lacepède, 1800) & 425 & - \\
\hline & & Auxis thazard thazard (Lacepede, 1800) & 37 & - \\
\hline \multirow[t]{6}{*}{2} & Carangidae & Parastromateus niger (Bloch, 1795) & 136 & - \\
\hline & & Decapterus russelli (Ruppell, 1830) & 287 & - \\
\hline & & Megalaspis cordyla (Linnaeus, 1758) & 97 & - \\
\hline & & Carangoides malabaricus (Bloch and Schneider, 1801) & 64 & - \\
\hline & & Chorinemus orientalis (Temminck and Schleyel, 1844) & 22 & - \\
\hline & & Scomberoides tol (Cuvier, 1832) & 14 & - \\
\hline \multirow[t]{2}{*}{3} & Terapontidae & Terapon jarbua (Forsskal, 1775) & 312 & - \\
\hline & & Terapon puta Cuvier, 1829 & 89 & - \\
\hline \multirow[t]{2}{*}{4} & Dussumieriidae & Dussumieria acuta Valenciennes, 1847 & 422 & - \\
\hline & & Dussumieria elopsoides Bleeker, 1849 & 122 & - \\
\hline \multirow[t]{3}{*}{5} & Pristigasteridae & Ilisha melastoma (Bloch and Schneider, 1801) & 798 & - \\
\hline & & Pellona ditchela Valenciennes, 1847 & 928 & - \\
\hline & & Ilisha megaloptera (Swainson, 1839) & 222 & - \\
\hline \multirow[t]{12}{*}{6} & Clupeidae & Escualosa thoracata (Valenciennes, 1847) & 803 & - \\
\hline & & Opisthopterus tardoore (Cuvier, 1829) & 398 & - \\
\hline & & Tenualosa ilisha (Hamilton, 1822) & 318 & - \\
\hline & & Anodontostoma chacunda (Hamilton, 1822) & 144 & - \\
\hline & & Sardinella albella (Valenciennes, 1847) & 313 & - \\
\hline & & Sardinella fimbriata (Valenciennes, 1847) & 89 & - \\
\hline & & Amblygaster clupeoides Bleeker, 1849 & 49 & - \\
\hline & & Sardinella gibbosa (Bleeker, 1849) & 375 & - \\
\hline & & Amblygaster sirm (Walbaum, 1792) & 42 & - \\
\hline & & Sardinella melanura (Cuvier, 1829) & 395 & - \\
\hline & & Hilsa kelee (Cuvier, 1829) & 79 & - \\
\hline & & Tenualosa toli (Valenciennes, 1847) & 284 & - \\
\hline \multirow[t]{2}{*}{7} & Stromateidae & Pampus argenteus (Euphrasen, 1788) & 131 & - \\
\hline & & Pampus chinensis (Euphrasen, 1788) & 87 & - \\
\hline 8 & Ambassidae & Ambassis ambassis (Lacepède, 1802) & 596 & - \\
\hline 9 & Dasyatidae & Himantura bleekeri (Blyth, 1860) & 27 & - \\
\hline 10 & Megalopidae & Megalops cyprinoides (Broussonet, 1782) & 187 & - \\
\hline \multirow[t]{6}{*}{11} & Engraulidae & Coilia dussumieri Valenciennes, 1848 & 280 & - \\
\hline & & Stolephorus commersonii Lacepede, 1803 & 859 & - \\
\hline & & Thryssa dussumieri (Valenciennes, 1848) & 366 & - \\
\hline & & Thryssa malabarica (Bloch, 1795) & 502 & - \\
\hline & & Thryssa mystax (Bloch and Schneider, 1801) & 381 & - \\
\hline & & Thryssa setirostris (Broussonet, 1782) & 376 & - \\
\hline \multirow[t]{2}{*}{12} & Ariidae & Plicofollis tenuispinis (Day, 1877) & 123 & - \\
\hline & & Hexanematichthys sagor (Hamilton, 1822) & 96 & - \\
\hline
\end{tabular}


Table 2 List of marine fishes examined from Malabar Coast, India, during the period from November 2009 to November 2012 (Continued)

\begin{tabular}{|c|c|c|c|c|}
\hline & & Arius acutirostris Day, 1877 & 44 & - \\
\hline \multirow[t]{3}{*}{13} & Hemiramphidae & Hemiramphus far (Forsskal, 1775) & 45 & - \\
\hline & & Hemiramphus lutkei (Valencinnes, 1847) & 85 & - \\
\hline & & Rhynchorhamphus malabaricus Collette, 1976 & 48 & - \\
\hline \multirow[t]{4}{*}{14} & Belonidae & Strongylura strongylura (van Hasselt, 1823) & 134 & + \\
\hline & & Strongylura leiura (Bleeker, 1850) & 408 & - \\
\hline & & Tylosurus acus melanotus Bleeker, 1850 & 19 & - \\
\hline & & Tylosurus crocodilus crocodilus (Peron and Lesuer, 1821) & 94 & - \\
\hline \multirow[t]{4}{*}{15} & Leiognathidae & Gazza minuta (Bloch, 1795) & 93 & - \\
\hline & & Eubleekeria splendens (Cuvier, 1829) & 108 & - \\
\hline & & Photopectoralis bindus (Valenciennes, 1835) & 35 & - \\
\hline & & Leiognathus sp & 29 & - \\
\hline \multirow[t]{2}{*}{16} & Cynoglossidae & Cynoglossus dubius Day, 1873 & 306 & - \\
\hline & & Cynoglossus arel (Bloch and Schneider, 1801) & 293 & - \\
\hline 17 & Trichiuridae & Lepturacanthus savala (Cuvier, 1829). & 34 & - \\
\hline \multirow[t]{2}{*}{18} & Mugilidae & Mugil cephalus Linnaeus, 1758 & 96 & - \\
\hline & & Mugil curema Valenciennes, 1836 & 39 & - \\
\hline 19 & Sphyraenidae & Sphyraena forsteri Cuvier, 1829 & 21 & - \\
\hline \multirow[t]{2}{*}{20} & Lutjanidae & Lutjanus johni (Bloch, 1792) & 29 & - \\
\hline & & Lutjanus malabaricus (Bloch and Schneider, 1801). & 32 & - \\
\hline 21 & Nemipteridae & Nemipterus japonicus (Bloch, 1791) & 22 & - \\
\hline \multirow[t]{3}{*}{22} & Exocoetidae & Cypselurus oligolepis (Bleeker, 1865) & 34 & - \\
\hline & & Exocoetus volitans Linnaeus, 1758 & 23 & - \\
\hline & & Parexocoetus mento (Valenciennes, 1847) & 15 & - \\
\hline 23 & Chanidae & Chanos chanos (Forsskal, 1775) & 26 & - \\
\hline 24 & Carcharhinidae & Rhizoprionodon acutus (Rüppell, 1837) & 39 & - \\
\hline 25 & Hemiscyllidae & Chiloscyllium punctatum Müller and Henle, 1838 & 62 & - \\
\hline 26 & Chirocentridae & Chirocentrus dorab (Forsskal, 1775) & 25 & - \\
\hline 27 & Muraenidae & Strophidon sathete (Hamilton, 1822) & 9 & - \\
\hline 28 & Muraenesocidae & Congresox talabonoides (Bleeker, 1853) & 7 & - \\
\hline 29 & Sillaginidae & Sillago sihama (Forsskal, 1775) & 22 & - \\
\hline 30 & Menidae & Mene maculata (Bloch and Schneider, 1801) & 29 & - \\
\hline 31 & Polynemidae & Eleutheronema tetradactylum (Shaw, 1804) & 32 & - \\
\hline 32 & Cichlidae & Etroplus suratensis (Bloch, 1790) & 76 & - \\
\hline 33 & Labridae & Parajulis poecilepterus (Temminck and Schlegel, 1845) & 37 & - \\
\hline 34 & Bagridae & Mystus gulio (Hamilton, 1822) & 27 & - \\
\hline 35 & Rachycentridae & Rachycentron canadum (Linnaeus, 1766) & 12 & - \\
\hline
\end{tabular}

yellow colour, the size being 1.2 to $1.3 \mathrm{~mm}$. Early-staged tissue differentiation seems to occur during ES I, and the embryo at this stage attains subspherical or ovoid shape without changing the colour from the preceding stage. The ES II-staged marsupiumite is characterized by the development of cephalic lobe, early limb bud and pigmented eye spot, and at this stage, the embryo becomes elongated. Marsupiumite at ES III appears as curved and segmented with thoracic and abdominal limb buds. By this stage (ES III), the embryonic development seems to be completed, and the egg gets ready to hatch out the larva called pre-manca; within the marsupium, it moults and transforms into the manca. Significantly, within the marsupium, the development of marsupiumites of $C$. 
Table 3 Parasitological index of the parasitic cymothoid Cymothoa frontalis, along the Malabar Coast, India

\begin{tabular}{|c|c|c|c|c|c|c|c|}
\hline \multirow[t]{2}{*}{ Parasite and host fish } & \multirow[t]{2}{*}{ NFE } & \multirow[t]{2}{*}{ NFI } & \multirow[t]{2}{*}{$P$} & \multicolumn{4}{|c|}{$\operatorname{TNP}(l)$} \\
\hline & & & & $\mathrm{F}$ & $\mathbf{T}$ & $M$ & $J$ \\
\hline Cymothoa frontalis Milne Edward,1840 & 134 & 92 & 68.65 & 67 & 14 & 68 & 22 \\
\hline Strongylura strongylura (Belonidae) & & & & 171 & & & \\
\hline
\end{tabular}

$P$, prevalence; NFE, number of fishes examined; NFI, number of fishes infested; TNP, total number of collected parasites; I intensity of infestation; $\mathrm{F}$, female of $C$. frontalis; $T$, transitional of $C$. frontalis; $M$, male of $C$. frontalis; J, juvenile stage of $C$. frontalis.

frontalis is synchronous evidenced by the presence of only one of the aforesaid developmental stages at a time. After a brief period of residence in the marsupium, the manca is seen released into the surrounding water where it leads a free swimming life. (During the present study, the free swimming manca was successfully reared for a maximum of 8 days in our laboratory.) Subsequently, manca enters into the infectious stage, quite likely as a single pair by parasitizing its host fish (S. strongylura). Through moulting, the paired manca becomes the juveniles which are usually found attached to the mucous membrane of the lower beak of the host (Figure 1G). Both members of the juvenile pair would undergo moulting (sequential?) which in turn induces remarkable morphological changes, leading to their transformation into functional paired males which settle within the host's buccal cavity. Within the buccal cavity, both males undergo moulting. However, by this process one of the (male) members becomes transitional but retains some of the male characters (Figure $7 \mathrm{C}, \mathrm{D}, \mathrm{E}$ ). The transitional further undergoes two sequential moults; interestingly, by the culmination of the second moult (also referred to

Table 4 Life cycle of Cymothoa frontalis

\begin{tabular}{|c|c|c|c|}
\hline \multicolumn{3}{|c|}{ Stages of life cycle } & \multirow{2}{*}{$\begin{array}{l}\text { Remarks } \\
\text { Round or oval, light florescent yellow (size: } 1.2 \text { to } 1.3 \mathrm{~mm} \text { ) }\end{array}$} \\
\hline Marsupial stage & Zygotic stage & & \\
\hline & Embryonic stages (ES) & ESI & $\begin{array}{l}\text { Subspherical to ovoid embryo, structural differentiation not evident, light florescent } \\
\text { yellow in colour (size: } 1.3 \text { to } 1.5 \mathrm{~mm} \text { length and } 1.25 \text { to } 1.3 \mathrm{~mm} \text { width) }\end{array}$ \\
\hline & & ES ॥ & $\begin{array}{l}\text { Elongate/oblong embryo with a cephalic end and early limb bud developed. } \\
\text { Pigmentation in the eyespot started. (size: } 1.6 \text { to } 1.85 \mathrm{~mm} \text { length and } 1.3 \text { to } 1.35 \mathrm{~mm} \\
\text { width) }\end{array}$ \\
\hline & & ES III & $\begin{array}{l}\text { Curved and segmented embryos with pigmented eyespots, thoracic and abdominal limb } \\
\text { buds appeared. Dorsal surface shows chromatophores. (size: } 1.9 \text { to } 2.0 \mathrm{~mm} \text { length and } 1.3 \\
\text { to } 1.400 \mathrm{~mm} \text { width) }\end{array}$ \\
\hline & Larval stages & Pre-manca & $\begin{array}{l}\text { The first hatched larvae remain in the marsupium and undergo moulting to transform } \\
\text { into manca. (Description is given in the text) }\end{array}$ \\
\hline & & Manca & $\begin{array}{l}\text { Final marsupial stage released in the surrounding medium. (Description is given in the } \\
\text { text) }\end{array}$ \\
\hline Free living stage & Manca & & Free swimming stage. Swim and search for specific host (S. strongylura) \\
\hline \multirow[t]{10}{*}{ Infective stage } & Manca & & $\begin{array}{l}\text { Infectious stage attaches to the host (S. strongylura) and then undergoes moulting to } \\
\text { transform into juvenile }\end{array}$ \\
\hline & Juvenile & & It undergoes moulting to transform into male. (Description is given in the text) \\
\hline & Male & & $\begin{array}{l}\text { It undergoes a moulting process and enters into the transitional stage. (Description is } \\
\text { given in the text) }\end{array}$ \\
\hline & Transitional stage & & $\begin{array}{l}\text { It undergoes a moult to transform into the female stage } 1 \text { (Fs 1). (Description is given in } \\
\text { the text) }\end{array}$ \\
\hline & Female & Fs 1 & $\begin{array}{l}\text { Ovigerous female with fully grown ovary and with newly formed brood plates, but no } \\
\text { marsupiumites. Undergo oviposition to form Fs } 2\end{array}$ \\
\hline & & Fs 2 & $\begin{array}{l}\text { Ovigerous female with growing ovary and carry first set of brood and marsupiumites } \\
\text { show synchrony in their development }\end{array}$ \\
\hline & & Fs 3 & $\begin{array}{l}\text { Ovigerous female with growing ovary and carrying empty old brood pouch, after } \\
\text { releasing manca. It undergoes a moult to transform into Fs } 4\end{array}$ \\
\hline & & Fs 4 & $\begin{array}{l}\text { Ovigerous female with growing ovary and no brood pouch/brood plates. It undergoes a } \\
\text { moult to transform into Fs } 5\end{array}$ \\
\hline & & Fs 5 & $\begin{array}{l}\text { Ovigerous female with newly formed brood plates but no marsupiumites. It undergoes } \\
\text { oviposition to form Fs } 6\end{array}$ \\
\hline & & Fs 6 & $\begin{array}{l}\text { Ovigerous female carrying second brood and marsupiumites show synchrony in their } \\
\text { development }\end{array}$ \\
\hline
\end{tabular}




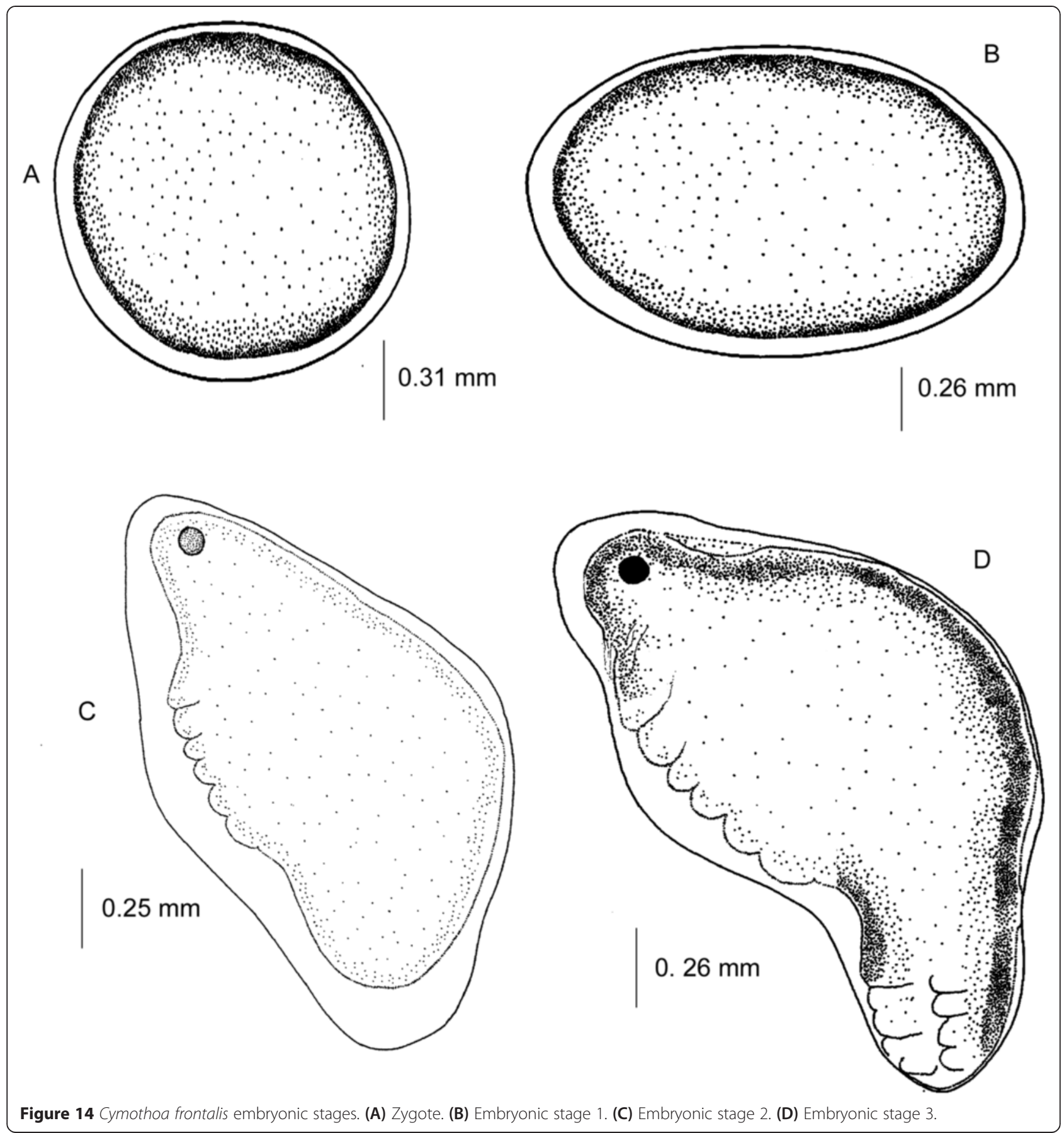

as 'oostegition moult'), it transforms into an ovigerous female with brood pouch or marsupium (a cavity formed by the overlapped, plate-like oostegites developed from the endopodites of the second, third, fourth and sixth pereopods). The female life is continued further by engaging itself in reproduction and also in parental care, by keeping the eggs and larvae in their brood pouch, until they are released. The brood pouch is formed and removed in an alternative manner through oostegition and de-oostegition moults, respectively; oostegition moult occurs before the oviposition (spawning), followed by marsupial life and larval (manca) release, after which deoostegition moult ensues. Based on the presence or absence of the brood pouch and/or marsupiumites, six consecutive stages of the ovigerous female (Fs 1 through Fs 6) were identified (Figure 15 and Table 4). The Fs 1-staged female that developed right from the transitional through the first oostegition moult is characterized by the presence of a growing ovary and a well-developed marsupium, but without marsupiumites; oviposition ensues and the eggs 


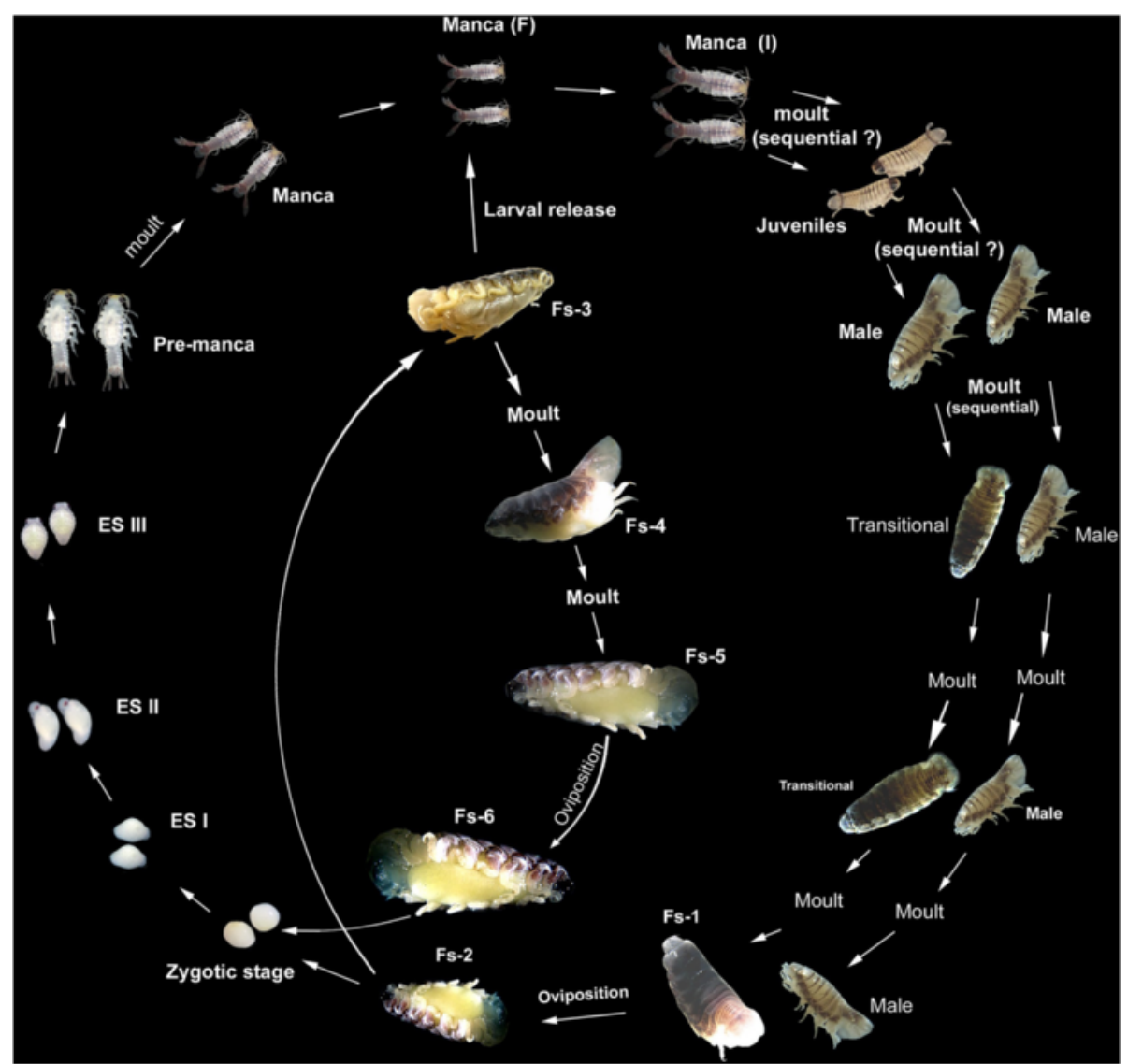

Figure 15 Schematic representation of the life cycle of Cymothoa frontalis. Manca (F), manca at free living stage; Manca (I), manca at infestive stage; ES, embryonic stage; Fs, female stage.

are deposited in the marsupium and this brooded ovigerous female is designated to be at Fs 2. Upon completion of the marsupial life, manca are released and the female with the old empty marsupium is referred to be at Fs 3 stage. The females at Fs 3 stage undergo de-oostegition moult (to remove the old marsupium) and enter Fs 4 stage, during which time it undergoes oostegition moult and transforms into Fs 5 stage with newly formed second marsupium and growing ovary. Excepting the meagre size difference and for the presence of a well-developed oostegial lobe of the maxilliped, the females at Fs 5 stage morphologically resemble the females at Fs 1 stage. Subsequent to oviposition, the females at Fs 5 would be transformed into Fs 6 stage, characterized by the presence of a second set of marsupiumites. Except the size differences, the females at Fs 6 stage would resemble those at Fs 2 stage.

\section{Discussion}

With the redescription of the females of $C$. frontalis and the description (of the transitional stage, the male, the juvenile and the larvae) as depicted in the present paper, we update the diagnosis of the species (C. frontalis) carried out by Milne Edwards (1840) and Schioedte and
Meinert (1884); to our knowledge, this report appears to be the first of its kind, wherein the cymothoid crustacean is being described by collating the data from all the stages in its life cycle.

The presence of transitional stage, as observed in the life cycle of $C$. frontalis (present study), is an indication of the protandrous sex reversal, akin to what has been reported in other cymothoids (Bowman 1960; Williams and Williams 1985; Tsai and Dai 1999). Significantly, at this (transitional) stage, C. frontalis is found to retain some of the male characteristics including the appendix masculina and two spines on the median and lateral lobes of the maxilla; the penes, however, become rudimentary at this stage. After its transformation into the ovigerous female, the spines on the lateral lobe of maxilla are reduced to one and the appendix masculina and penes are seen to have completely disappeared.

Apart from the intense body tanning, the presence of plumose setae on the oostegial lobe of the maxilliped (Figure $2 \mathrm{H}$ ) during the female phase makes $C$. frontalis distinct from those of other cymothoids described so far. On the other hand, C. frontalis resembles another cymothoid such as Cymothoa spinipalpa (described by 
Thatcher et al. 2007) in the possession of folded endopodite of the fourth and fifth pleopod.

The pre-manca and manca of $C$. frontalis possess appendages in all pereonites except the seventh one. In pre-manca, pereopods lack spines and there are no setae on pleopods, uropod and pleotelson. Manca, on the other hand, possesses six pairs of spiny pereopods, and their pleopods, uropod rami, pleotelson are with plumose setae facilitating the free swimming life. The toothed dactylus on the first three pairs of pereopods would help the larva (manca) to cling on to the host fish during the infective stage. Contrary to this, in the manca of Agarna malayi and $N$. indica, the dactyli of all pereopods are devoid of teeth; teeth are, however, present on the propodus of the first three pereopods (Aneesh et al., unpublished). In pre-manca and manca of $C$. frontalis, the uropod basis and subequal rami are extremely extended beyond the distal margin of the pleotelson. Such an extension is not prominent in the case of the cymothoid $M$. renardi (Aneesh et al., unpublished). In the juvenile stage of $C$. frontalis, pleopodal setae and pareopodal spines and teeth are found to be more or less in a reduced state. By the onset of the adult male stage, all these structures completely disappeared and the limbs become short; the carapace gets gradually calcified and arched with intense tanning. In the female stage, the telson is kept in an upright position enabling the pleopods under constant vibration to aerate the marsupiumites.

Notwithstanding the fact that a single host 'Cyclopterus' was doubtfully reported by White (1847), until now, the host fish of $C$. frontalis was not accurately identified. Out of the 80 fish species examined during the present study, $C$. frontalis was recovered only from the belonid fish S. strongylura, showing its oligoxenous host specificity. Rarely though, oligoxenous host specificity has also been reported in other cymothoid species such as $N$. indica, M. renardi and $N$. longispina parasitizing $R$. kanagurta, S. leiura and A. ambassis, respectively (Aneesh et al. 2011, 2013a, b).

In C. frontalis, broods are held in the female marsupium. This observation agrees with the previous reports on other cymothoids Elthusa vulgaris (Brusca 1978), Anilocra pomacentri (Adlard and Lester 1995) and Glossobius hemiramphi (Bakenhaster et al. 2006). The life cycle of $C$. frontalis passes through marsupial, free living and infective phases. During the marsupial phase, six sequential and morphologically distinct stages including one zygotic, three embryonic (ES I-III) and two larval stages (pre-manca and manca) are completed. Marsupiumites of cymothoids E. vulgaris, A. pomacentri and $G$. hemiramphi have also been reported to have five distinct ontogenic stages (Brusca 1978; Adlard and Lester 1995; Bakenhaster et al. 2006). The synchronized pattern of marsupial development as observed in $C$. frontalis (present study) looks comparable with what was reported in G. hemiramphi (Bakenhaster et al. 2006). However, in C. frontalis, the exact duration of the successive development of each marsupial stage from their preceding stage is not clear. The final marsupial stage (manca) of $C$. frontalis showed close resemblance to that of A. pomacentri (Adlard and Lester 1995) and C. spinipalpa (Thatcher et al. 2007). In A. pomacentri, the manca is released within 2 days after they appeared in the marsupium (Adlard and Lester 1995). In the present study, it is observed that after a brief period of marsupial residence, the manca of $C$. frontalis is released into the water and lead a free swimming life until it infests the host fish $(S$. strongylura). Deviating from this pattern, the manca of $G$. hemiramphi have been shown to infest other species of fish temporarily, before settling on its specific host Hemiramphus brasiliensis (Bakenhaster et al. 2006). The exact mechanism that helps manca to find its specific host is unclear. The physical characteristics of this larval form are suggested to facilitate precise attachment to the specific host (Bakenhaster et al. 2006). Evidences are not available to suggest if the environmental cues or host-derived factors are likely to influence the host-specific attachment. The success rate of the larvae for host attachment is also not available.

From the manca stage of $C$. frontalis, the transformation to successive stages (juveniles, male, transitional and female stages) is accomplished by the intervening moult. The present report on the existence of six successive stages (Fs 1 to Fs 6 ) of the ovigerous females of $C$. frontalis could be considered first of its kind due to a paucity of any such attempt on other cymothoid species.

Admittedly, the duration of the life cycle of $C$. frontalis could not be assessed during the present study. Previous reports suggest that the average duration to complete the life cycle of cymothoids is nearly 1 year; the entire life cycle of G. hemiramphi on its fish host (H. brasiliensis) is completed within 1 year (Bakenhaster et al. 2006). In $A$. pomacentri, the female without dislodging from the host or host death was shown to have an average life span of 13.5 months (Adlard and Lester 1995).

\section{Conclusions}

Not only would the present redescription of the female and description of the remaining stages in the life cycle of C. frontalis provide us with added information on its biology, but the study would also help us identify the cymothoid parasite very precisely. Further, the observations made through the present study could give us valuable cues for identification of other (parasitic) cymothoids as well. The occurrence of ovigerous females of $C$. frontalis at different reproductive phases throughout the study period indicates its high fecundity rate which could be a parasitic adaptation. Further, very pertinently, the features 
such as strict host specificity, site specificity, high rate of prevalence, characteristic life cycle stages, protandric hermaphroditism, the existence of different classes of ovigerous females and occurrence of fecund females all the way through different moult stages make $C$. frontalis an ideal model organism to study the physiological basis of parasitism and hermaphroditism which in turn would be helpful to study the strategies to be adopted for the management of parasites infesting edible fishes.

\section{Abbreviations}

LT: Total length; MNHN: National Museum of Natural History of Paris, France; PCM: Parasitic Crustacean Museum, Crustacean Biology Research Laboratory, Sree Narayana College, Kannur, Kerala, India.

\section{Competing interests}

The authors declare that they have no competing interests.

\section{Authors' contributions}

APT is the main worker on the topic and prepared the draft of the manuscript. SK is the mentor who critically followed the work with timely discussion, interpreted the results and corrected the manuscript. HAK helped the main worker for observation and identification, helped in the drawing and is involved in the interpretation of results. AG critically reviewed the manuscript and made significant comments for the improvement of the paper. TJP helped to describe and redescribe the specimen and compared with the type material, reviewed the article and made necessary corrections/modifications. All authors read and approved the final manuscript.

\section{Acknowledgements}

The authors gratefully acknowledge University Grant Commission, New Delhi (F.No: 38-218/2009 (SR); dated: 24/12/2009) and Kerala State Council for Science Technology and Environment, Government of Kerala (No. (T) 093/SRS/2011/CSTE; dated: 25/06/2011) for financial support to carry out this work.

\section{Author details}

${ }^{1}$ Post Graduate Department of Zoology and Research Centre, Sree Narayana College, Kannur 670 007, India. ${ }^{2}$ School of Biosciences and Technology, VIT University, Vellore 632014, Tamil Nadu, India. ${ }^{3}$ UMR 5119 (CNRS-UM2-IRD-UM1-IFREMER), Equipe Adaptation Ecophysiologique et Ontogenèse, University of Montpellier 2, CC. 092, 34095 Montpellier, Cedex 05, France.

Received: 21 September 2014 Accepted: 29 April 2015

Published online: 20 May 2015

\section{References}

Adlard RD, Lester RJG (1995) The life-cycle and biology of Anilocra pomacentri (Isopoda, Cymothoidae), an ectoparasitic isopod of the coral-reef fish, Chromis nitida (Perciformes, Pomacentridae). Aust J Zool 43(3):271-281. doi:10.1071/ZO9950271

Aneesh PT (2014) Studies on parasitic crustaceans infesting the fishes of Malabar Coast, Ph. D. thesis, Kannur University

Aneesh PT, Sudha K, Arshad K, Anilkumar G, Trilles JP (2011) Studies on the occurrence of Norileca indica (Milne Edwards), a parasitic cymothoid, parasitizing the Indian mackerel, Rastrelliger kanagurta (Scomberidae) from the Malabar coast of Kerala. In: Abstract volume of national conference on emerging trends in biological research, Madras University, Chennai, 21-22 February, 2011, 51

Aneesh PT, Sudha K, Arshad K, Anilkumar G, Trilles JP (2013a) Seasonal fluctuation of the prevalence of cymothoids representing the genus Nerocila (Crustacea, Isopoda), parasitizing commercially exploited marine fishes from the Malabar Coast, India. Acta Parasitol 58(1):80-90. doi:10.2478/s11686-013-0112-3

Aneesh PT, Sudha K, Helna AK, Arshad K, Anilkumar G, Trilles JP (2013b) Simultaneous multiple parasitic crustacean infestation on banded needlefish, Strongylura leiura (Belonidae) from the Malabar Coast, India. Int I Scientific Res Publications 3(7):367-375
Aneesh PT, Sudha K, Helna AK, Anilkumar G, Trilles J-P (2014) Multiple parasitic crustacean infestation on belonid fish Strongylura strongylura. In: Wehrtmann IS, Bauer RT (eds) Proceedings of the summer meeting of the Crustacean Society and the Latin American Association of Carcinology, Costa Rica, July 2013. ZooKeys 457:339-353

Avdeev W (1978) Notes on the distribution of the marine Cymothoidae (Isopoda, Crustacea) in the Australian-New Zealand region. Folia Parasitol 25:281-283

Avdeev W (1979) New species of the genus Cymothoa (Isopoda, Cymothoidae) from the coastal regions of Northern and North-Western Australia. Parazitologiya 13:50-55

Avdeev W (1990) Morpho-physiological adaptation in ecto and mesoparasitic Isopoda of the suborder Flabellifera. Zoologicheski Zhurnal SSSR (en Russse) 69:33-42

Bakenhaster MD, McBride RS, Price WW (2006) Life history of Glossobius hemiramphi (Isopods: Cymothoidae): development, reproduction, and symbiosis with its host Hemiramphus brasiliensis (Pises: Hemiramphidae). J Crustacean Biol 26(3):283-294

Bowman TE (1960) Description and notes on biology of Lironeca puhi, n.sp. (Isopoda, Cymothoidae), parasite of the Hawaiian Moray Eel, Gymnothorax eurostus (Abbott). Crustaceana 1:82-91

Bowman TE, Mariscal RN (1968) Renocila heterozoata, a new cymothoid isopod, with notes on its host, the anemone fish Amphiprion akallopisos, in the Seychelles. Crustaceana 14:97-104

Brusca RC (1978) Studies on the cymothoid fish symbionts of the eastern Pacific (Crustacea: Isopoda: Cymothoidae). II. Systematics and biology of Lironeca vulgaris Stimpson 1857. Allan Hancock Occasional Papers New Series 2:1-19

Brusca RC (1981) A monograph on the Isopoda Cymothoidae (Crustacea) of the eastern Pacific. Zool J Linnean Soc 73:117-199

Bush AO, Lafferty KD, Lotz JM, Shostak AW (1997) Parasitology meets ecology on its own terms: Margolis et al. revised. J Parasitol 83:575-583

Dana JD (1853) Crustacea, Part II. Fam. Cymothoidae. In: United States Exploring Expedition during the Years 1838, 1839, 1840, 1841, 1842, under the command of Charles Wilkes, U.S.N. Vol. 14, C. Sherman, Philadelphia, 746-65.

Fabricius JC (1793) Entomologia Systematica emendata et acuta, secundum classes, ordines, genera, species adjectis synonimis, locis, observationibus, descriptionibus. Christ. Gottl. Proft., Hafniae, 519

Froese R, Pauly D (2012) FishBase. World Wide Web electronic publication. Available from: http:// www. Fishbase org, Version (March 2013).

Gerstaecker A (1901) Isopoda. In Dieklassen and ordnungen der. Arthropoden, wissenschaftlich dargestelt in wort and Bild., Funther Band. II Abtheilung. Crustacea (ed. H. B. Bronn), 8-278. C. F. Wintersche verlagshandlung

Gopalakrishnan A, Rajkumar M, Jun S, Trilles J-P (2010) Occurrence of double parasitism on black-barred halfbeak fish from the southeast coast of India. Chinese J Oceanol Limnol 28:832-835

Hadfield KA, Bruce NL, Smit NJ (2011) Cymothoa hermani sp. nov. (Isopoda, Cymothoidae, Crustacea), a parasitic isopod, collected off the Zanzibar coast, Tanzania from the mouth of a parrotfish (Scaridae). Zootaxa 2876:57-68

Hadfield KA, Bruce NL, Smit NJ (2013) Review of the fish-parasitic genus Cymothoa Fabricius, 1793 (Isopoda, Cymothoidae, Crustacea), from the southwestern Indian Ocean, including a new species from South Africa. Zootaxa 3640:152-176

Heller C (1868) Crustaceen, Ordo Isopoda. In: Reise der Österreichischen Fregatte Novara um die Erde in den Jahren 1857, 1858, 1859 unter den Befehlen des Commodore B. von Wüllerstorf- Urbair. Zoologischer Theil, Zweiter Band, III Abtheilung. Aus der Kaiserlich-Königlichen Hof- und Staatsdruckerei, Wien, 130-147.

Horton T, Okamura B (2001) Cymothoid isopod parasites in aquaculture: a review and case study of a Turkish sea bass (Dicentrarchus labrax) and sea bream (Sparus auritus) farm. Dis Aquat Organ 46:181-188

Kussakin OG (1979) Marine and brackish water isopod Crustacea. Suborder Flabellifera. Akademy of Science, U.S.S.R

Margolis L, Esch GW, Holmes JC, Kuris AM, Schad GA (1982) The use of ecological terms in parasitology (report of an ad hoc Committee of the American Society of Parasitologists). J Parasitol 68:131-133

Milne Edwards H (1840) Histoire Naturelle des Crustacés comprenant l.anatomie, la physiologie et la classification de ces animaux. Vol. II. Librairie Encyclopédique de Roret, Paris

Nierstrasz HF (1931) Die Isopoden der Siboga Expedition. 3. Isopoda Genuina. 2. Flabellifera. Siboga-Expeditie 32:123-233 
Rajkumar M, Perumal P, Trilles JP (2006) A note on the double parasitism (Copepod and Isopod) in Commerson's Anchovy fish (India). J Environ Biol 27:613-614

Ramakrishna G (1980) Techniques of collection and preservation of parasitic crustaceans. In: Proceedings of workshop - techniques in parasitology. Zoological Survey of India 109-113

Richardson H (1905) A monograph on the isopods of North America. Bulletin United States National Museum 54:1-727

Romestand B, Trilles J-P (1977) Dégénérescence de la langue des Bogues (Boops boops L., 1758) (Téléostéens, Sparidae) parasités par Meinertia oestroides (Risso, 1826) (Isopoda, Flabellifera, Cymothoidae). Zeitschrift fur Parasitenkunde 54:47-53

Sartor SM, Pires AM (1988) The occurrence of Cymothoa liannae, a new species of cymothoid isopod from Brazil, with a comparative study of its post-marsupial development. Crustaceana 55:147-156

Schioedte JC, Meinert F (1884) Symbolae ad monographiam Cymothoarum Crustaceorum Isopodum Familiae. IV. Cymothoidae. TRIB. II. Cymothoinae. TRIB. III. Livonecinae. Naturhistorisk Tidsskrift, Ser. III, XIV: 221.454, pls VI. XVIII (Cym. XXIV. XXXVI).

Schotte M, Boykon CB, Bruce NL, Poore GCB, Taiti S, Wilson GDF (Eds) (2008 onwards). World list of marine freshwater and terrestrial isopod crustaceans. Available online at http://www.marinespecies.org/isopoda. [Accessed 19 Oct 2010]

Seng LK, Seng LT (1990) The Genus Nerocila (Isopoda: Flabellifera) from the marine fish Triacanthus breverostris, Penang, Malaysia. J Biol Sci 1:87-100

Sudha K, Supriya NT, Krishnakumar V, Anilkumar G, Chang ES (2012) Hemolymph ecdysteroid titres in a brachyuran crab (Uca triangularis) that concomitantly undergoes molting and reproduction. Zool Stud 51(7):966-976

Thatcher VE, de Loyola J, Silva E, Jost GF, Souza-Conceicao JM (2003) Comparative morphology of Cymothoa spp. (Isopoda, Cymothoidae) from Brazillian fishes, with the description of Cymothoa catarinensis sp. Nov. and redescription of C. excise Perty and C. oestrum (Linnaeus). Rev Bras Zool 2:541-552

Thatcher VE, de Araujo GS, TAX de lima J, Chellappa S (2007) Cymothoa spinipalpa sp. nov. (Isopoda, Cymothoidae) a buccal cavity parasite of the marine fish, Oligoplites saurus (Bloch \& Schneider) (Osteichthyes, Carangidae) of Rio Grande do North State, Brazil. Rev Bras Zool 24:238-245

Trilles J-P (1968) Recherches sur les Isopodes "Cymothoidae" des côtes francaises. Vol. 1 : bionomie et parasitisme. Vol. 2. Biologie generale et. Sexualite. Deuxieme these, Systematique et faunistique. University of Montpellier, France, No. Enregistrement CNRS AO2305

Trilles J-P (1975) Les Cymothoidae (Isopoda, Flabellifera) des collections du Museum national d'Histoire naturelle de Paris. III. Les Cymothoinae Schioedte et Meinert, 1884. Genre Cymothoa Fabricius, 1787. Bulletin du Muséum National d' Histoire Naturelle, Paris 3ème série, n 318, Zoologie 225:977-993

Trilles J-P (1994) Les Cymothoidae (Crustacea, Isopoda) du monde. Prodrome pour une faune. Studia Marina 21/22 (1-2) (1991): 5-288

Trilles J-P, Bariche M (2006) First record of the Indo-Pacific Cymothoa indica (Crustacea, Isopoda, Cymothoidae), a Lessepsian species in the Mediterranean Sea. Acta Parasitol 51:223-230

Trilles J-P, Hipea-Jacquotte R (2012) Symbiosis and parasitisme in the Crustacea. In traité de zoologie by P.P. Grassé, J. Forest and c. von Vaupel Klein (Eds). The Crustacea 3:239-319

Trilles J-P, Ravichandran S, Rameshkumar G (2011) A checklist of the cymothoidae (Crustacea, Isopoda) recorded from Indian fishes. Acta Parasitol 56(4):445-459

Tsai ML, Dai CF (1999) Ichthyoxenus fushanensis, new species (Isopoda: Cymothoidae) parasite of the freshwater fish, Varicorhinus bacbatulus, from northern Taiwan. J Crustacean Biol 19:917-923

White A (1847) List of the specimens of Crustacea in the collection of the British Museum. Printed by order of the Trustees, London, London

Williams LB, Williams EH Jr (1985) Brood pouch release of Anilocra chromis Williams and Williams (Isopoda: Cymothoidae) a parasite of brown chromis, Chromis multilineatus (Guichenot), in the Caribbean. Crustaceana: Int Crustacean Res 49:92-95

\section{Submit your manuscript to a SpringerOpen ${ }^{\odot}$ journal and benefit from:}

- Convenient online submission

- Rigorous peer review

- Immediate publication on acceptance

- Open access: articles freely available online

- High visibility within the field

- Retaining the copyright to your article

Submit your next manuscript at springeropen.com 